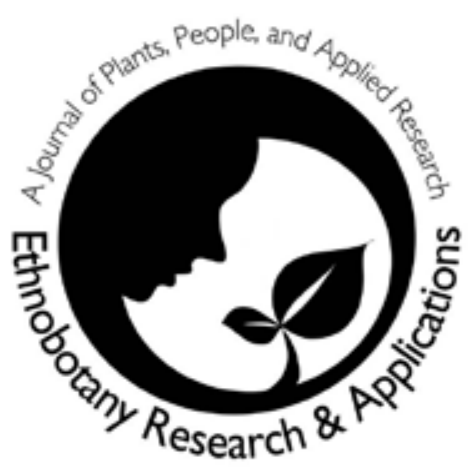

\title{
Herbal Bouquets Blessed on Assumption Day in South- Eastern Poland: Freelisting versus photographic inventory
}

\author{
Łukasz Łuczaj
}

\section{Research}

\begin{abstract}
Herbal bouquets are blessed all over Poland on Assumption Day (August $15^{\text {th }}$ ). They used to contain many species of crops and medicinal herbs, mainly collected from the wild. Due to transformations in landscape and lifestyle in rural areas, the composition of the bouquets has been changing. The aim of the study was to document the present composition of bouquets using photographs (etic perspective) and questionnaires (emic perspective). The questionnaires asked informants about perceived changes in the bouquets over their lifetime, and the results are supplemented with some $19^{\text {th }}$ and $20^{\text {th }}$ century local publications.
\end{abstract}

The study was carried out in SE Poland, around the towns of Krosno and Jasło. Photographs of 174 bouquets were taken, and 133 questionnaires, mainly from older informants, were obtained. On average a photographed bouquet contained nearly eight species of plants and an average informant knew of the use of over ten species in a bouquet. The frequency of species in photos and questionnaires was surprisingly similar. However in questionnaires people did not usually list ornamental flowers, now increasingly present in the bouquets, and listed several plants which used to be blessed (e.g. Papaver somniferum L., Calendula officinalis L., Chamomilla recutita (L.) Rauschert) yet were hardly ever seen in photos.

Bukiety zielne są od wieków święcone w dniu Matki Boskiej Zielnej (15 sierpnia). Zwykle zawierały one rośliny uprawowe i lecznicze, także te zbierane ze stanu dzikiego. Z powodu przemian krajobrazu i gospodarki rolnej skład bukietów ulega zmianie. Celem tej pracy była dokumentacja stanu zachowania tradycji z dwóch perspektyw: zdjęć obecnie święconych bukietów (etic) i kwestionariuszy, gdzie respondenci wymieniali jakie rośliny się święci i jakie święcono dawniej (emic). Dodatkowo wyniki badań porównano z miejscowymi pracami etnograficznymi z XIX i XX wieku.

Do badań wybrano okolice Jasło i Krosna, w granicach zasięgu kultury Pogórzan. Sfotografowano 174 bukiety (głównie żywe, w dzień święcenia). Zebrano 133 kwestionariusze, głównie od osób starszych. Bukiety zawierały średnio prawie osiem gatunków roślin, a respondenci wymieniali średnio dziesięć gatunków. Częstość roślin na zdjęciach i w bukietach była dosyć podobna. Jednak w kwestionariuszach respondenci wymieniali także rośliny już nie święcone, np. mak lekarski, nagietki i rumianek, a nie wymieniali roślin ozdobnych, częstych na zdjęciach.

\section{Introduction}

\section{Studies of Assumption Day \\ blessing rituals in Poland}

Up until the turn of the $19^{\text {th }}$ and $20^{\text {th }}$ century peasants of many European countries, including the present territo-

\section{Correspondence}

Łukasz Łuczaj, Academy of Humanities and Economics in Łódź, ul. Rewolucji 1905 r. nr 64, 90-222 Łódź, POLAND. and The Wild Garden, Pietrusza Wola 86, 38-471, POLAND.

lukasz.luczaj@interia.pl

Ethnobotany Research \& Applications 9:001-025 (2011)

Published: January 20, 2011 
ry of Poland, lived in very primitive conditions, depending almost solely on local food and other natural resources. This resulted in their being closely linked to the plant world, with an extensive knowledge of plants and their uses which had the same level of complexity as many tropical tribes studied by contemporary ethnobotanists. These traditions are documented by a few hundred Polish ethnographic sources, as listed by Klepacki (2007).

Life in rural Poland was strongly tied to the cycle of seasonal agricultural activities. Apart from rational farming practices, ritual acts were employed to provide for the well-being of the farm, and their main purposes were either to protect from magical 'evil' influences (apotropaic) or to increase the fertility of crops (Ruszel 2004). The vast majority of Polish farmers are Roman-Catholic. However Christianity was introduced here later than in western and southern Europe (at the turn of the $10^{\text {th }}$ and $11^{\text {th }}$ century) and in peasant culture it formed an amalgamate with older pagan traditions, similar to the result of the process which took place when Christianity was introduced in Central and South America. Due to the small amount of preChristian written records, it is now difficult to distinguish which of the traditions concerning the ritual use of plants come from that period, which of them developed later and which are of foreign import, e.g., through medieval herbals (Ruszel 2004). Regardless of these uncertainties we can state that in the $19^{\text {th }}$ century the traditional use of plants was strongly entwined with Catholic holidays. The rich list of holidays, including the days of particular patron saints, helped peasants to organize their farming activities, as they were usually linked to a period between or after a certain holiday, e.g., on the $8^{\text {th }}$ of September ('Virgin Mary of Sowing') sowing of cereals was started, on the $2^{\text {nd }}$ of July (Virign Mary of Berries) the berry harvest was started in the woods. Certain taboos were associated with these dates, e.g., collecting forest fruits before the $2^{\text {nd }}$ of July would result in depriving dead children, who lived in heaven on forest berries, of food (Ruszel 2004).

One of the most important points in the annual calendar of events was the blessing of plants in churches on certain dates (Paluch 1984, Ruszel 2004), e.g., in spring, on Palm Sunday (Niedziela Palmowa) and on the eighth day after Corpus Christi, in June (Oktawa Bożego Ciała). The day on which the largest number of plants was blessed was Zielna - the $15^{\text {th }}$ of August (Assumption Day). On this day specially arranged bouquets were brought to churches. They usually contained cereals, other crops, medicinal plants and apotropaic plants. Similar Assumption Day customs can be found in a few other Central European countries, particularly Austria and Germany, where the holiday is usually called Mariä Himmelfahrt (Aumüller 1974, Christanell et al. 2010, Höfler 1912, Schroedel \& Schroedel 2006, Sillasoo 2009). Rostafiński (1922) derives plant blessing on Assumption Day directly from the Jewish holiday Yom ha-Bikkurim (Day of the First Fruits, Shavuot), which was adopted by eastern Christianity and, at the end of the sixth century, transferred to the $15^{\text {th }}$ of August. Blessing 'Assumption bundles' has been practiced in Europe since medieval times (Höfler 1912), at least from the $9^{\text {th }}$ century, and is well-rooted in Roman-Catholic liturgy, where special prayers for crop and herb blessings exist (Schroedel \& Schroedel 2006). Once an important and widespread custom, now it survives only in certain regions of Europe and has lost its high cultural importance (Christanell et al. 2010, Paluch 1984, Ruszel 2004).

Assumption Day is an important Christian holiday, celebrated in the Catholic and Orthodox church. According to the oral Christian tradition Virgin Mary did not die but was taken to heaven with her body. This interpretation of the tradition was officially confirmed by Pope Pius XII in 1950 in his Apostolic Constitution Munificentissimus Deus. This belief is known to the Orthodox Church as the Dormition. Actually, there is no link between the theological meaning of the holiday and the tradition of blessing plants on that day, apart from the fact that, according to medieval legends, lilies were found in Mary's grave (Rostafiński 1922). The holiday must simply have been a convenient day to perform this ritual.

The tradition of Zielna bouquets is well known in Poland, at least among middle-aged and elderly members of the Catholic and Orthodox church, and most local ethnographic studies throughout Poland mention this custom, sometimes even listing a few plants which are blessed. However, little is known about the state of the preservation of the tradition or the exact composition of the bouquets. With this in mind, in 2008 an individual research program was started by the author, devoted to the photographic documentation of bouquets blessed in churches, and this paper is the third report from this project (Łuczaj 2009a, 2011).

The present study is not the first attempt to thoroughly document the blessed plants. At the turn of the $19^{\text {th }}$ and $20^{\text {th }}$ century Seweryn Udziela (1857-1937), an ethnographer from Kraków, gathered extensive information on the ethnobotany of the Kraków area (Udziela 1931). His work contains detailed records on the use of plants in ethnomedicine and rituals, including plants blessed in churches on Assumption Day (the $15^{\text {th }}$ of August). His study is thoroughly documented with voucher specimens (probably gathered between 1894 and 1899), and may be the earliest example of a European study in which voucher specimens were used intentionally to document ethnobotanical data. His collection is stored in the herbarium of the Institute of Botany of the Polish Academy of Sciences (KRAM). Piotr Köhler (1996a, 1996b) reexamined the herbarium, confirming the identification of most specimens and correcting a few mistaken identifications (Köhler 1996a). In 2009 I took photos of the bouquets in the villages previously studied by Udziela. Within the last 110 years strong changes in the composition of the bouquets occurred, caused mainly by habitat transformations, particularly the 


\section{Łuczaj - Herbal Bouquets Blessed on Assumption Day in South-Eastern Poland: Freelisting versus photographic inventory}

disappearance of species-rich pastures and meadows (Łuczaj 2011).

Valuable information on the custom was collected in the second half of the $19^{\text {th }}$ century by Oskar Kolberg. In his monograph of Polish folk customs, he often referred to plant blessing. Unfortunately he only occasionally wrote down the scientific equivalent of the reported folk names. Józef Rostafiński, a botanist contemporary to Udziela and Kolberg, also attempted to study the custom. In his 70 question survey published in several newspapers he included a question concerning the composition of the bouquets (Köhler 1993). However he added this question in a later version of the questionnaire and received only a few responses to this issue, and this part of his study remained unpublished.

Many references to the plants blessed in flower bouquets can also be found in Paluch's (1984) monograph of Polish medical ethnobotany and in Libera and Paluch's monograph of medicinal plants of the Lasowiacy group north of Rzeszów (Libera \& Paluch 1993).

\section{Studies of the bouquets blessed by Pogórzanie}

The aim of this study is to characterize the composition of Assumption Day bouquets in a small area, a part of the Podkarpackie administrative region (Figure 1). The

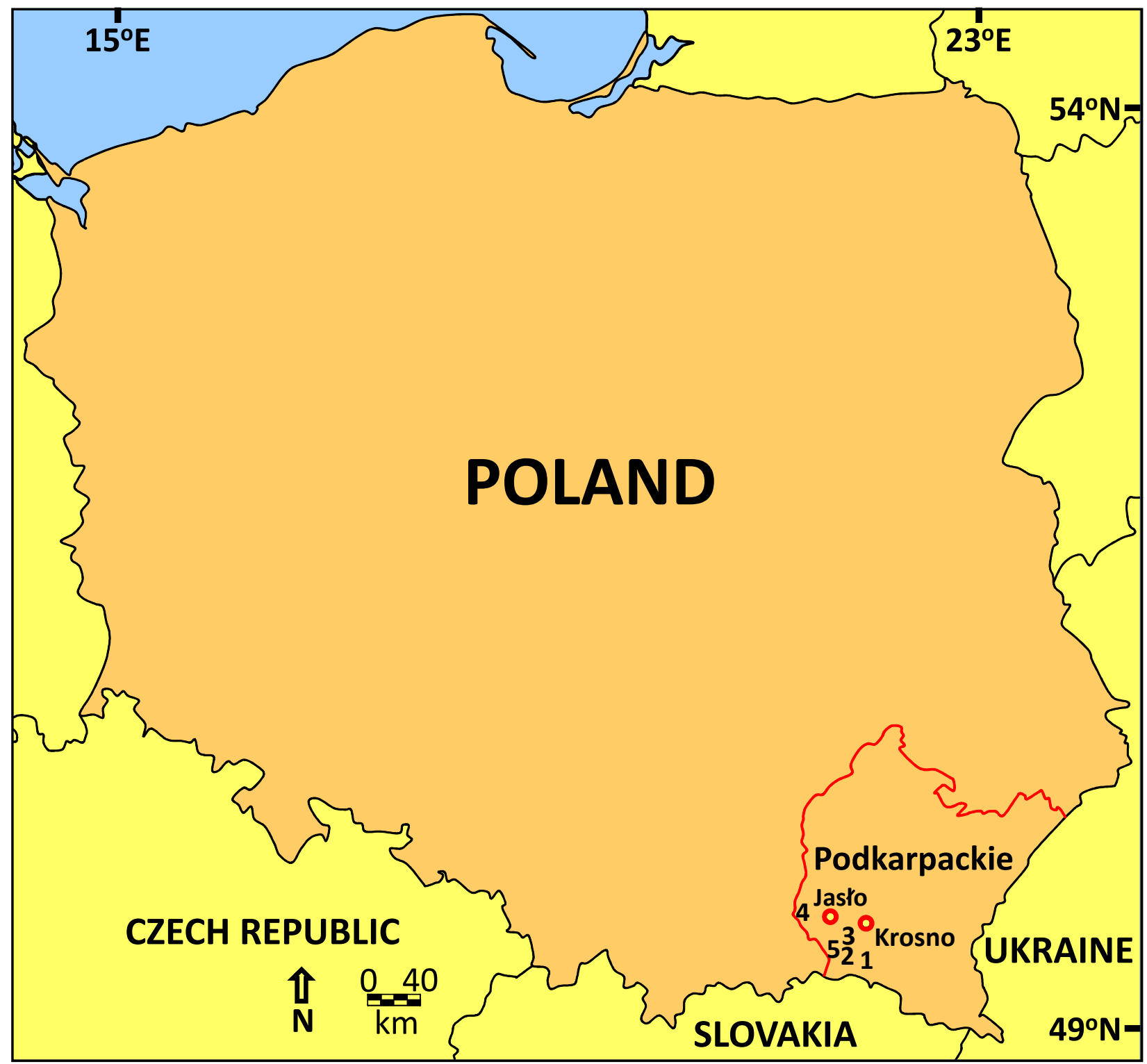

Figure 1. Podkarpackie administrative region, Poland where Assumption Day bouquets were studied. Study area villages with more than 12 bouquets: 1 Dukla, 2. Łysa Góra, 3. Nienaszów, 4. Sławęcin, and 5. Stary Żmigród. 


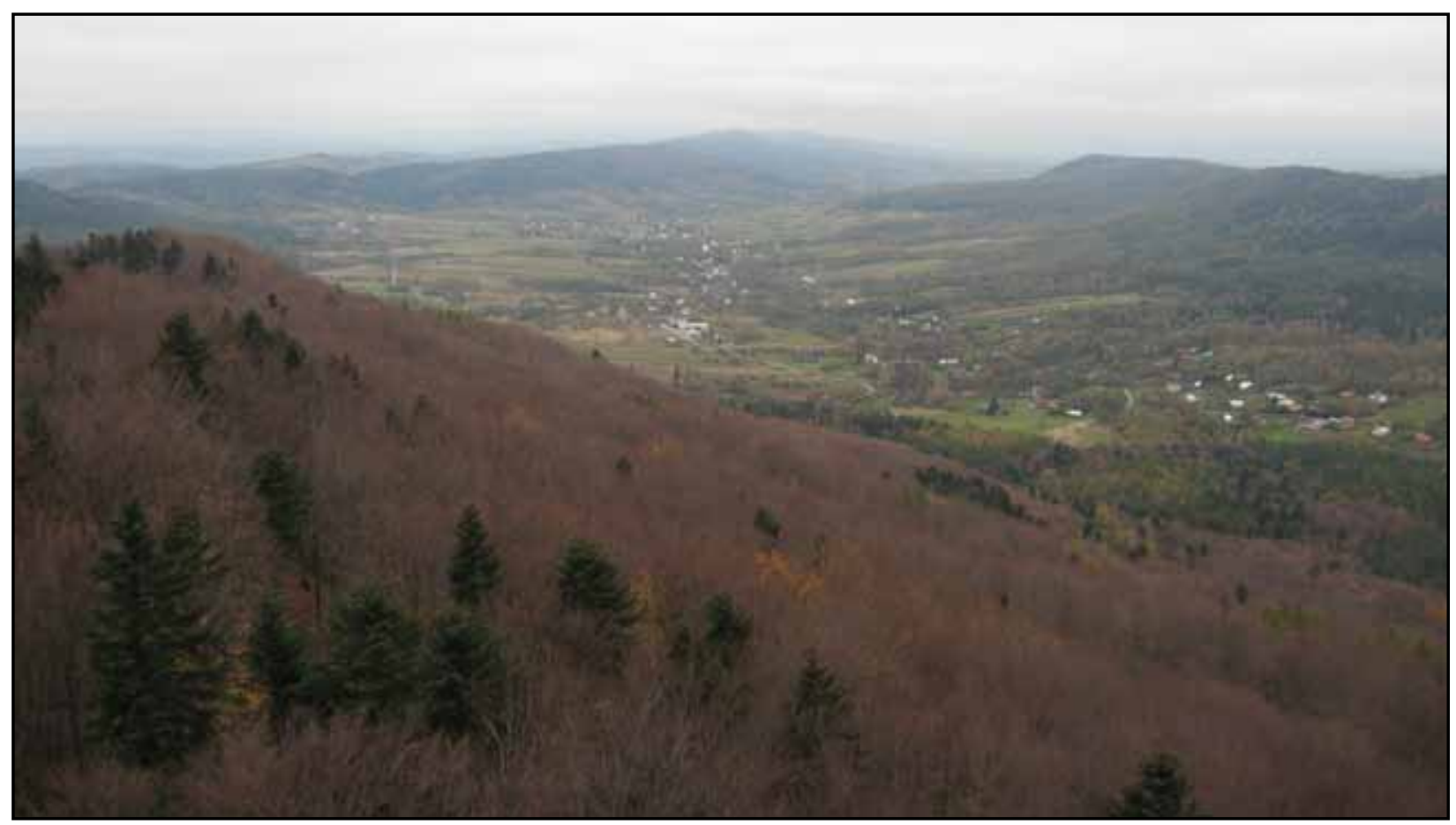

Figure 2. A typical landscape of the Podkarpackie administrative region of Poland where Assumption Day bouquets were studied.

area chosen is inhabited by a Polish cultural group called Pogórzanie, thus the whole area has a homogenous material and spiritual culture. The Pogórzanie inhabit a part of the Carpathian Foothills around the towns of Biecz, Jasło, Krosno, Strzyżów, Brzozów and Rymanów. The Pogórzanie is not a group with any form of self-identity but a cultural area artificially defined by ethnographers on the basis of material culture and local customs. Nearly the whole population is Roman-Catholic, of Polish descent with a considerable admixture of German colonizers who arrived there in medieval times and are now completely Polonized (Ruszel 2004).

This area is particularly suitable for the study as it has both a relatively rich rural culture and well preserved semi-natural grasslands, which form the largest reservoir of medicinal plants traditionally blessed in the bouquets. The study area has a cold temperate climate (mean temperature is around $8 \mathrm{C}$, mean July temperature is $18 \mathrm{C}$, mean January temp. $-4 \mathrm{C}$, mean annual rainfall -700 $800 \mathrm{~mm}$ per year) intermediate between maritime and continental. It is moderately densely inhabited (population density around 100 per $\mathrm{km}^{2}$ ). The landscape is a mosaic of rural settlements, small towns, hay meadows, arable fields, pastures and woodland (Figure 2). Within the last few decades there has been a tendency to abandon farming. Many agricultural plots were turned into woodland or became old fields overgrown by tall perennials. The majority of the population now lives on work outside farms, mainly in the largest towns of the region (e.g., Krosno and Jasło), or periodic work abroad. Unemployment is high and the mean income per capita is lower than the national average. On the other hand most families in the studied places own their own piece of land and grow vegetables, although animal husbandry is only restricted to a fraction of the families. It is still very common for extended families to live together in one house, which facilitates the vertical transfer of traditional knowledge, particularly as grandparents are the most important childcare resource for parents. The majority of the population is Roman-Catholic. Nearly all children attend religion lessons at school and most people regularly attend Sunday services at church.

A few authors have briefly described the tradition of blessing bouquets in the area. Lidia Maria Czyż (1993) wrote an account of the blessing in a few Virgin Mary sanctuaries in the Rzeszów area. One of the studied churches lies within the area of this research. Krzysztof Ruszel (2004) also made a description of the custom in the whole Podkarpacie region in his encyclopedia of folk culture.

Three authors - Oskar Kolberg, Bolesław Tync and Janina Łozińska - gave accounts of the blessing tradition in the $19^{\text {th }}$ century in villages on the edge of the study area. Kolberg (1974) listed 24 species from Wzdów near Brzozów. Tync (1994) reported the use of 42 taxa from the Biecz area (10 in common with Kolberg). Łozińska (1883) said, in her archival letter to Rostafiński, that people in Turaszówka and Krosno bless four wild species plus all garden flowers (the letter is stored in the museum of the Botanic Garden of Jagiellonian University). However Łozińska was a local landowner, not a practicing ethnog- 


\section{Łuczaj - Herbal Bouquets Blessed on Assumption Day in South-Eastern Poland: Freelisting versus photographic inventory}

rapher (like the two former authors) and her account is the least reliable.

\section{Emic and etic}

A picture of the past and present nature of the tradition was obtained by comparing historical data, results of questionnaires from knowledgeable local people and photos of bouquets to compare the emic and etic vision of the bouquets. The emic-etic opposition is often applied in cultural anthropology (Headland et al. 1990) and is used in ethnobotany (Cotton 1996, Martin 1995, Zent 1996), for example when considering the difference between folk taxa and scientific taxa (Berlin 1992) or estimating the extent of use of non-timber forest products (Wong 2000, Zent 1996).

Zent (1996) defined these terms as follows:

"An emic point of view corresponds to the perceptions, nomenclature, classifications, knowledge, beliefs, rules and ethics of the local plant world as defined by a native of the local cultural community."

"An etic perspective denotes the conceptual categories and organization of the ethnobotanical environment according to the researcher, who is often an alien to the local culture and whose conceptual system ideally derives from the language and rules of science."

Unfortunately there are relatively few examples of ethnobotanical studies where emic and etic data are explicitly compared using statistical procedures. Although the use of the terms emic and emic is often criticized in anthropology due to a the vagueness of the concepts, fully realizing the two extremes: the insider and outsider perceptions, with which we can approach a cultural phenomenon, can be very fruitful. Finding a discrepancy between these visions may provide us with new insight into a cultural phenomenon (Headland et al. 1990).

\section{Methods}

A list of taxa mentioned in Kolberg's and Tync's publications and in Łozińska's letter was made. Around half of the folk names from these sources were identified, as the same names are commonly used nowadays in the studied area or adjacent regions.

The bouquets were recorded using digital photographs. The photos were taken before and during masses on Assumption Day (the $15^{\text {th }}$ of August), in 2008 (Dukla, Stary Żmigród, Łysa Góra and Nienaszów) or 2009 (KrosnoBiałobrzegi). I also received 13 photos from Ms. Anna Jeleń from Sławęcin near Biecz taken in 2008 and in 2008-2009 took a few photos of dried bouquets in the houses of some respondents.
The bouquets were photographed from a distance of 50$100 \mathrm{~cm}$, sometimes an additional photo was taken from a different angle. A database with the species composition of the bouquets was made. Unidentified taxa were also recorded in order to count the species number per bouquet.

Photographs are an undervalued tool for ethnobotanical study, mainly due to concerns about the ability to identify taxa using photographs. However, their use is probably going to increase (Thomas et al. 2007)

People's perception of bouquets and the knowledge of species used in them were assessed using questionnaires. The questionnaires were distributed to middleaged or elderly Roman-Catholics who themselves take part in the tradition (oldest respondent -88 years old, youngest -44 , mean age -69 ). The majority of people were female (only four men were interviewed). All of them were either farmers or grew up on farms. Most respondents were perceived by the locals as relatively knowledgeable people in the field of traditions or herbalism. The questionnaire consisted of open questions (freelisting) about the plants blessed on the $8^{\text {th }}$ day after Corpus Christi and on Assumption Day. The questions concerning the latter holiday were as follows (see Polish original text in Appendix 1):

1. What plants are blessed on Assumption Day?

2. Are there any plants which used to be blessed and are not blessed now? Until when were they blessed and why did the custom stop?

3. How were the bouquets used afterwards?

4. Are any of the blessed plants regarded as father, mother, king or queen of herbs, or as the most important of all the herbs?

Respondents filled in the questionnaires themselves or were interviewed and their responses noted down by the interviewer. Weather permitting, some taxa mentioned by the respondents were identified in the field. However, as most questionnaires were completed indoors, also in winter, we may expect that the respondents knew more blessed plants than they actually listed. They may have particularly omitted some covert taxa, which they recognize, but cannot name.

It must be emphasized that the two parts of the study were done in the same area but in a different set of villages the questionnaires were distributed in a large number of places, so could give a richer set of species than if they were distributed only in the few villages where the photographs were collected. 


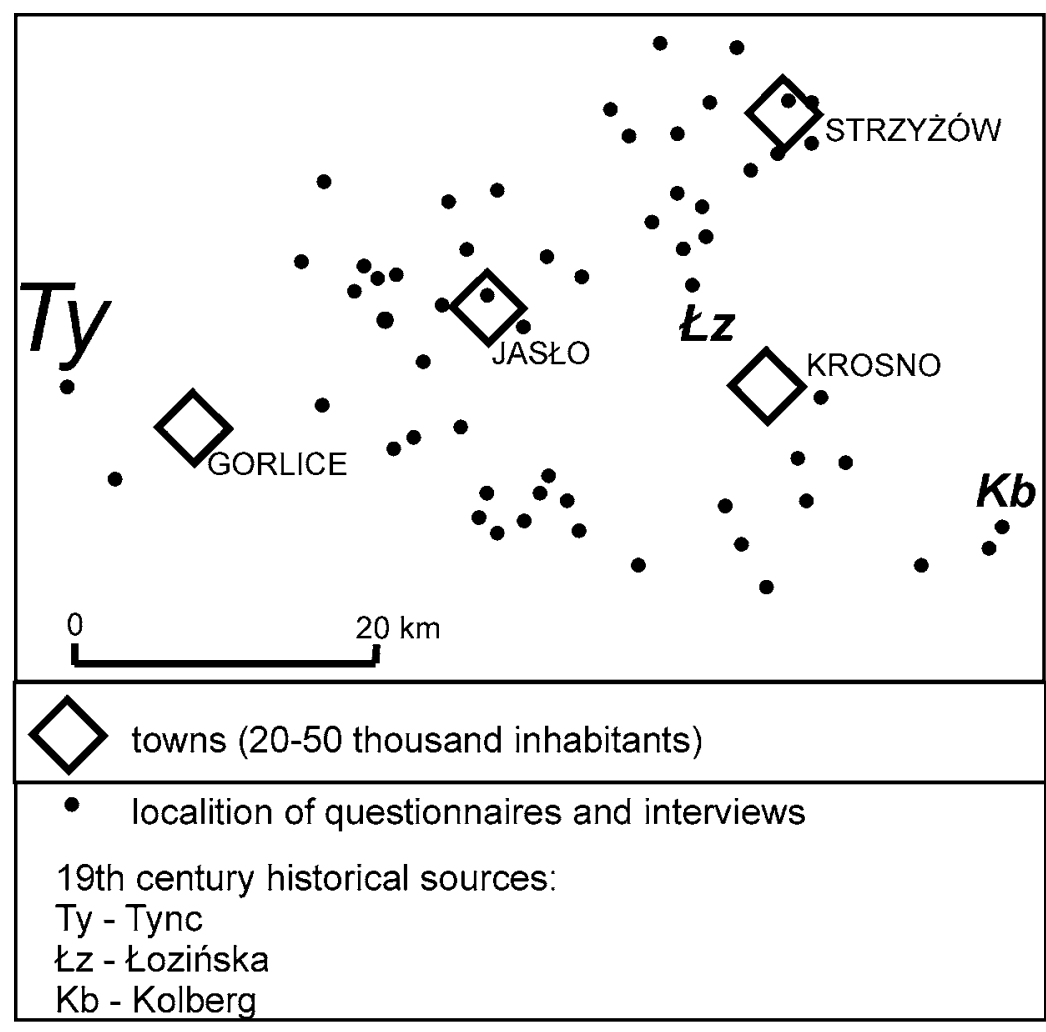

Figure 3. Distribution of questionnaries and interviews about Assumption Day bouquests in Podkarpackie administrative region, Poland.

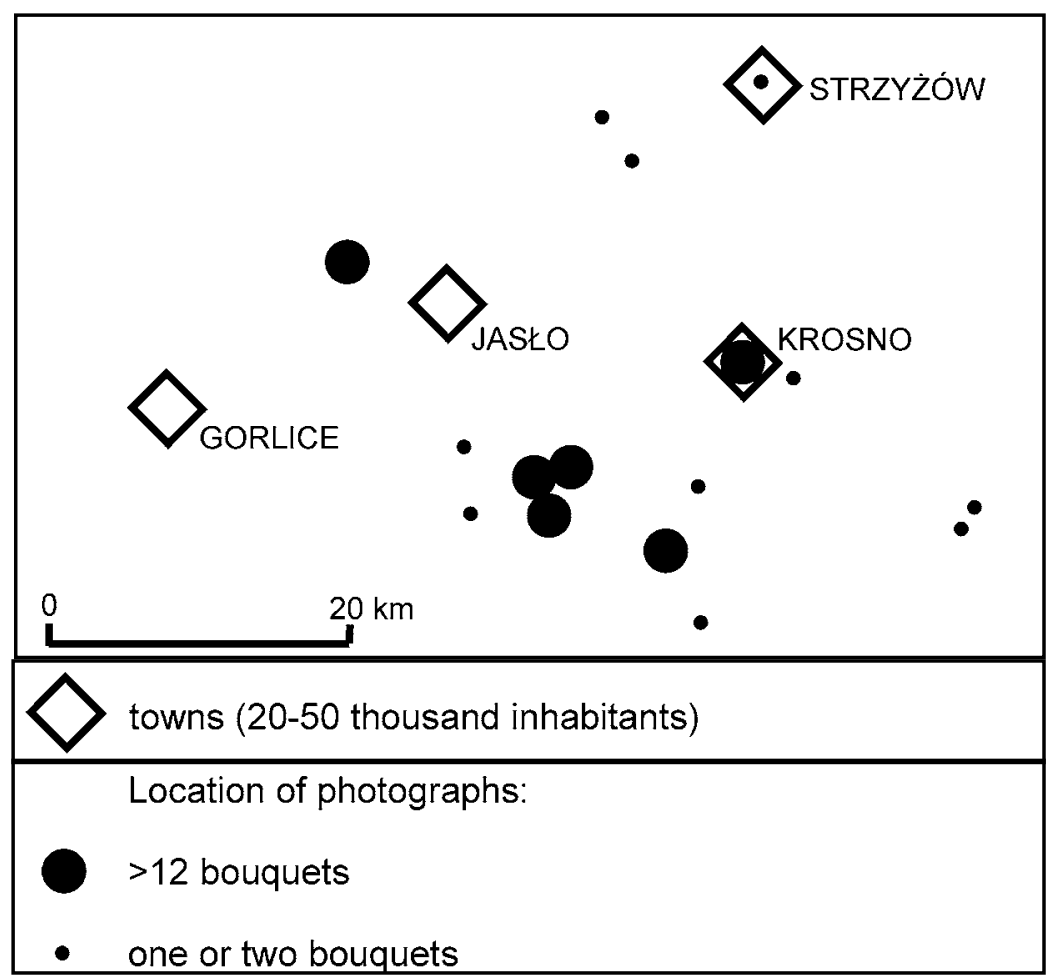

Figure 4. Distribution of bouquets photographed on Assumption Day in Podkarpackie administrative region, Poland.

\section{Results}

Quantitative results of the questionnaire and photographs

Altogether 133 respondents from 57 settlements (villages and towns) filled out the questionnaires (Figure 3 ). A total of 193 taxa were identified to a genus or species level (Tables 1, 2) - 150 taxa in the photographs and 116 taxa in the questionnaires. (Additional taxa are noted in Appendix 2). There were 7.6 species per blessed bouquet according to the photos (altogether 162 fresh bouquets and 12 dry ones were photographed, Figure 4). The means for villages are as follows: Łysa Góra - 7.2, Stary Żmigród - 8.1, Nienaszów - 8.3, Sławęcin - 8.3, a small town, Dukla, had 8.2 , whereas the bouquets in the largest town of the area (Krosno, fifty thousand inhabitants) had 5.5 species. An average questionnaire respondent reported more species (mean $=10.3, \mathrm{SD}=4.8$, median $=10$ ), however it should be noted that the choice of respondents was biased towards older knowledgeable people and that the respondents also reported the taxa whose inclusion in bouquets is obsolete.

The plants which are blessed most frequently (Table 1) were: dill (Anethum graveolens L.), St. John's wort (Hypericum perforatum L.), guelder rose (Viburnum opulus L.), tansy (Tanacetum vulgare L.), wheat (Triticum sp.), apple (Malus pumila Mill.), dahlia (Dahlia sp.), sunflower (Helianthus annuus L.), oats (Avena sativa L.), zinnia (Zinnia elegans Jacq.), rowan (Sorbus aucuparia L.), yarrow (Achillea millefolium L.), mint (Mentha, mainly the wild Mentha longifolia (L.) Huds, and cultivated Mentha X piperita L.), and hazel (Corylus avellana L.). Opium poppy (Papaver somniferum L.) was mentioned in many questionnaires, but it is rarely blessed now, due to the official ban on its cultivation since 1990. On the other hand goldenrods were rarely mentioned in the questionnaires but are very frequently blessed.

Most species were recorded in photographs and in questionnaires, although for a large proportion of species there are significant differences between their 


\section{Łuczaj - Herbal Bouquets Blessed on Assumption Day in South-Eastern Poland: Freelisting versus photographic inventory}

Table 1. Most frequently blessed species (found in $>10$ photos or/and questionnaires) for Assumption Day bouquets in Podkarpackie administrative region, Poland. $P$ - significance of difference between the frequency in photos and questionnaires (Two Sample Z-test): ** $\mathrm{P}<0.001$; ${ }^{*} \mathrm{P}<0.05$; ns - not significant. XIX - presence in the $19^{\text {th }}$ century sources: T - Tync (1994), K - Kolberg (1974) , L - Łozińska (1883).

\begin{tabular}{|c|c|c|c|c|c|c|}
\hline Latin name & $\begin{array}{l}\text { Main local } \\
\text { name(s) }\end{array}$ & $\begin{array}{l}\% \text { of } \\
\text { photos }\end{array}$ & $\begin{array}{l}\% \text { of } \\
\text { questionnaire }\end{array}$ & $\begin{array}{l}\text { \% of } \\
\text { photos and } \\
\text { questionnaires }\end{array}$ & $\mathbf{P}$ & $\mathrm{XIX}$ \\
\hline Anethum graveolens L. & koper & 44.2 & 51.5 & 47.4 & ns & $\mathrm{T}$ \\
\hline Hypericum spp. & $\begin{array}{l}\text { dziurawiec, } \\
\text { dzwonki }\end{array}$ & 30.5 & 59.8 & 43.1 & ** & $\mathrm{T}$ \\
\hline Viburnum opulus L. & kalina & 42.5 & 37.9 & 40.5 & ns & $\mathrm{T}$ \\
\hline Tanacetum vulgare L. & $\begin{array}{l}\text { wrotycz, } \\
\text { rutycz, ruta etc. }\end{array}$ & 35.6 & 43.9 & 39.2 & ns & $\mathrm{T}$ \\
\hline Triticum sp. & pszenica & 40.8 & 28.8 & 35.6 & * & TK \\
\hline Malus pumila Mill. - fruit & jabłko & 19.0 & 50.8 & 32.7 & ** & TK \\
\hline Dahlia sp. & dalia, giergony & 41.4 & 18.2 & 31.4 & ** & \\
\hline Helianthus annuus L. & słonecznik & 22.4 & 33.3 & 27.1 & * & \\
\hline Avena sativa L. & owies & 27.0 & 22.0 & 24.8 & ns & \\
\hline Papaver somniferum L. & $\begin{array}{l}\text { mak, mak } \\
\text { ogrodowy }\end{array}$ & 1.7 & 44.7 & 20.3 & ** & $\mathrm{K}$ \\
\hline Zinnia elegans Jacq. & cynia & 31.0 & 5.3 & 19.9 & ** & \\
\hline Sorbus aucuparia L. & jarzębina & 9.2 & 30.3 & 18.3 & ** & $\mathrm{T}$ \\
\hline $\begin{array}{l}\text { Solidago gigantea Aiton \& S. } \\
\text { canadensis L. ( } 25 \text { photos), } \\
\text { Solidago virgaurea L. (14 photos) }\end{array}$ & nawłoć & 28.7 & 4.5 & 18.3 & ** & \\
\hline Achillea millefolium $\mathrm{L}$. & krwawnik & 16.7 & 17.4 & 17.0 & ns & \\
\hline Gladiolus sp. - garden varieties & mieczyk & 19.5 & 13.6 & 17.0 & ns & \\
\hline $\begin{array}{l}\text { Mentha spp. (the wild } M \text {. } \\
\text { longifolia (L.) Huds. and a few } \\
\text { cultivated taxa in the photos) }\end{array}$ & mięta, miętka & 9.2 & 27.2 & 17.0 & ** & TK \\
\hline Corylus avellana $\mathrm{L}$. & $\begin{array}{l}\text { orzech } \\
\text { laskowy }\end{array}$ & 10.3 & 21.2 & 15.0 & * & $\mathrm{T}$ \\
\hline Calendula officinalis $\mathrm{L}$. & $\begin{array}{l}\text { nagietki, } \\
\text { majgietki }\end{array}$ & 5.2 & 25.8 & 14.0 & ** & TK \\
\hline Secale cereale $\mathrm{L}$. & żyto & 10.3 & 18.2 & 13.7 & * & TK \\
\hline Phlox paniculata $\mathrm{L}$. & floks & 20.1 & 2.3 & 12.4 & ** & \\
\hline Origanum vulgare $\mathrm{L}$. & $\begin{array}{l}\text { ptasia mięta, } \\
\text { libiutka etc. }\end{array}$ & 17.2 & 5.3 & 12.1 & * & $\mathrm{K}$ \\
\hline Rudbeckia fulgida Aiton \& R. hirta L. & rudbekia & 18.4 & 0 & 10.5 & ** & \\
\hline Artemisia vulgaris L. & bylica & 7.5 & 11.4 & 9.1 & ns & $\mathrm{T}$ \\
\hline Rudbeckia laciniata L. 'Golden Glow' & rudbekia & 15.5 & 0 & 8.8 & ** & \\
\hline Tagetes patula L. & śmierdziuszki & 13.8 & 0.8 & 8.2 & ** & \\
\hline Hordeum vulgare L. & jęczmień & 0 & 18.1 & 7.8 & ** & \\
\hline Chamomilla recutita (L.) Rauschert & rumianek & 0 & 16.7 & 7.2 & ** & $\mathrm{T}$ \\
\hline Eupatorium cannabinum L. & $\begin{array}{l}\text { siedziec, } \\
\text { szadziec }\end{array}$ & 6.3 & 6.1 & 6.2 & ns & $\mathrm{K}$ \\
\hline Rosa spp.- garden cultivars & róża & 6.3 & 6.1 & 6.2 & ns & \\
\hline
\end{tabular}




\begin{tabular}{|c|c|c|c|c|c|c|}
\hline Latin name & $\begin{array}{l}\text { Main local } \\
\text { name(s) }\end{array}$ & $\begin{array}{l}\% \text { of } \\
\text { photos }\end{array}$ & $\begin{array}{l}\% \text { of } \\
\text { questionnaire }\end{array}$ & $\begin{array}{l}\text { \% of } \\
\text { photos and } \\
\text { questionnaires }\end{array}$ & $\mathbf{P}$ & $\mathrm{XIX}$ \\
\hline Centaurea jacea L. & $\begin{array}{l}\text { twarde ziele, } \\
\text { twardostój etc. }\end{array}$ & 5.2 & 6.8 & 5.9 & ns & \\
\hline Agrimonia eupatoria L. & $\begin{array}{l}\text { jabłuszka Matki } \\
\text { Bożej, Boże } \\
\text { jabłuszka etc. }\end{array}$ & 6.3 & 4.5 & 5.6 & ns & \\
\hline Allium cepa L. & cebula & 1.1 & 11.4 & 5.6 & ** & $\mathrm{K}$ \\
\hline Artemisia abrotanum L. & boże drzewko & 3.4 & 7.6 & 5.2 & ns & TK \\
\hline Thymus pulegioides L. & macierzanka & 0.6 & 11.4 & 5.2 & ** & \\
\hline Daucus carota L. - roots & marchew & 0.6 & 10.6 & 4.9 & $* *$ & \\
\hline Centaurium sp. & $\begin{array}{l}\text { cyntoria, } \\
\text { cyncylijka etc. }\end{array}$ & 2.3 & 7.6 & 4.6 & * & $\mathrm{T}$ \\
\hline $\begin{array}{l}\text { Chamaenerion angustifolium (L.) } \\
\text { Holub. \& Epilobium spp. }\end{array}$ & $\begin{array}{l}\text { paluszki Matki } \\
\text { Boskiej, etc. }\end{array}$ & 2.3 & 7.6 & 4.6 & * & $\mathrm{K}$ \\
\hline Artemisia absinthium L. & piołun & 0 & 10.6 & 4.6 & ** & $\mathrm{K}$ \\
\hline Lythrum salicaria L. & krowie ogony & 7.5 & 0.8 & 4.6 & * & \\
\hline Callistephus chinensis (L.) Nees & aster & 7.5 & 0 & 4.2 & * & \\
\hline Trifolium spp. & konicz & 2.3 & 6.8 & 4.2 & ns & $\mathrm{K}$ \\
\hline Centaurea cyanus L. & bławat & 1.7 & 7.6 & 4.2 & * & \\
\hline $\begin{array}{l}\text { Cirsium spp. (mainly Cirsium } \\
\text { oleraceum (L.) Scop.) }\end{array}$ & oset & 2.3 & 6.1 & 3.9 & ns & \\
\hline Papaver rhoeas L. & $\begin{array}{l}\text { mak czerwony, } \\
\text { panienki }\end{array}$ & 1.7 & 6.1 & 3.6 & * & \\
\hline
\end{tabular}

Table 2. Less frequently blessed species (recorded in 3-10 photos or questionnaires) for Assumption Day bouquets in Podkarpackie administrative region, Poland.

\begin{tabular}{|l|l|c|c|c|}
\hline Scientific name & Local name & Photos & Questionnaires & Altogether \\
\hline Salvia officinalis L. & szałwia & 1 & 9 & 10 \\
\hline Allium sativum L. & czosnek & 2 & 7 & 9 \\
\hline Cichorium intybus L. & przydrożnik, twardostój & 1 & 8 & 9 \\
\hline Gladiolus sp. (cultivated) & mieczyk & 9 & - & 9 \\
\hline Leucanthemum vulgare Lam. s.I. & $\begin{array}{l}\text { ślepie wronie, talerze, } \\
\text { króliki, rumian, } \\
\text { duże stokrotki }\end{array}$ & 9 & 9 \\
\hline Staphylea pinnata L. & kokoczka & & 5 & 9 \\
\hline Amaranthus sp. & proso tureckie & 4 & 4 & 8 \\
\hline Erigeron annuus (L.) Pers. & - & 4 & - & 8 \\
\hline Euphrasia rostkoviana Hayne & świetlik & 8 & 8 & 8 \\
\hline Nigella damascena L. & czarnuszka & & 5 & 8 \\
\hline Vitis sp. & winogron & 3 & 2 & 7 \\
\hline Althaea officinalis L. & prawoślaz & 6 & & 7 \\
\hline Carlina vulgaris L. s.l. & osetek Matki Bożej & 6 & & 7 \\
\hline Melissa officinalis L. & melisa & 3 & 5 & 7 \\
\hline
\end{tabular}


Łuczaj - Herbal Bouquets Blessed on Assumption Day in South-Eastern

Poland: Freelisting versus photographic inventory

\begin{tabular}{|c|c|c|c|c|}
\hline Scientific name & Local name & Photos & Questionnaires & Altogether \\
\hline Rumex spp. & szczaw, tatarczuch & - & 7 & 7 \\
\hline Aronia sp. & aronia & 3 & 3 & 6 \\
\hline Asparagus officinalis L. & asparagus & 6 & & 6 \\
\hline Knautia arvensis (L.) Coult. & & 5 & 1 & 6 \\
\hline Lavandula angustifolia Mill. & lawenda & 2 & 4 & 6 \\
\hline Levisticum officinale W.D.J.Koch & lubczyk & 1 & 5 & 6 \\
\hline Asarum europaeum L. & kopytnik, kopelnik & - & 5 & 5 \\
\hline Calamagrostis epigeios (L.) Roth & palma & 4 & 1 & 5 \\
\hline $\begin{array}{l}\text { Chrysanthemum sp.- } \\
\text { cultivated forms }\end{array}$ & chryzantema & 5 & - & 5 \\
\hline Ononis arvensis L. & wiatrowe ziele & 2 & 3 & 5 \\
\hline Phalaris arundinacea L. 'Zebrina' & - & 5 & & 5 \\
\hline Senecio nemorensis L. s.I. & tutoja, gwiazdki & 2 & 3 & 5 \\
\hline $\begin{array}{l}\text { Tanacetum parthenium (L.) } \\
\text { Sch.-Bip. }\end{array}$ & maruna & 2 & 3 & 5 \\
\hline Carum carvi L. & kminek & - & 4 & 4 \\
\hline Chelidonium majus L. & jaskółcze ziele & - & 4 & 4 \\
\hline Cosmos bipinnatus Cav. & - & 4 & - & 4 \\
\hline Crocosmia sp. & - & 4 & - & 4 \\
\hline Equisetum sp. & skrzyp & - & 4 & 4 \\
\hline Inula helenium L. & wielkie ziele & - & 4 & 4 \\
\hline $\begin{array}{l}\text { Petroselinum crispum (Mill.) } \\
\text { Fuss }\end{array}$ & pietruszka & 3 & 1 & 4 \\
\hline Polygonum spp. & rdest & 3 & 1 & 4 \\
\hline Sanguisorba officinalis L. & krwiściąg, przestrach & 3 & 1 & 4 \\
\hline Saponaria officinalis L. & - & 4 & - & 4 \\
\hline Verbascum sp. & dziewanna & & 4 & 4 \\
\hline Alcea rosea (L.) Cav. & malwa & 1 & 2 & 3 \\
\hline Astrantia major L. & - & 3 & - & 3 \\
\hline Buxus sempervirens L. & bukszpan & 3 & - & 3 \\
\hline Calluna vulgaris (L.) Hull & wrzos & 3 & - & 3 \\
\hline Dipsacus sp. & - & 2 & 1 & 3 \\
\hline Galium verum $\mathrm{L}$. & - & 2 & 1 & 3 \\
\hline Geranium pratense L. & - & 3 & - & 3 \\
\hline Glechoma hederacea L. & - & 3 & - & 3 \\
\hline Helenium autumnale L. & dzielżan & 3 & - & 3 \\
\hline Hydrangea sp. & hortensja & 3 & - & 3 \\
\hline Lamium album $\mathrm{L}$. & jasnota, głucha pokrzywa & 1 & 2 & 3 \\
\hline Limonium sp. & zatrwian & 3 & - & 3 \\
\hline Linum usitatissimum L. & Ien & - & 3 & 3 \\
\hline Malva sp. & ślaz & - & 3 & 3 \\
\hline Paeonia sp. & piwonia & - & 3 & 3 \\
\hline
\end{tabular}




\begin{tabular}{|l|l|c|c|c|}
\hline Scientific name & Local name & Photos & Questionnaires & Altogether \\
\hline Plantago sp. & babka & - & 3 & 3 \\
\hline Rosmarinus officinalis L. & rozmaryn & - & 3 & 3 \\
\hline Rudbeckia laciniata L. wild form & - & 3 & - & 3 \\
\hline Sambucus sp. & dziki bez & 1 & 2 & 3 \\
\hline Sedum sp. & rozchodnik & 2 & 1 & 3 \\
\hline Senecio sp. (cultivated) & - & 3 & - & 3 \\
\hline Tilia sp. & lipa & 1 & 2 & 3 \\
\hline $\begin{array}{l}\text { Viola arvensis Murray and/ } \\
\text { or Viola tricolor L. }\end{array}$ & bratki polne & - & 3 & 3 \\
\hline
\end{tabular}

frequency in photos and bouquets. Some species, e.g., from the genera Dahlia, Zinnia, Solidago and Phlox, are commoner in the photographs. These are garden flowers, which, although common, have little cultural importance, hence their relative absence in the questionnaires. On the other hand some plants are under-represented in the photographs. These in turn are plants which used to have high cultural importance but their use (for various reasons) are disappearing from the bouquets, e.g., St. John's wort (the most important medicinal herb, used mainly for gastrointestinal problems), opium poppy (an important ingredient of Christmas food), apples (the most important edible fruit), and marigold Calendula officinalis L. (once a commonly used ornamental and medicinal plant).

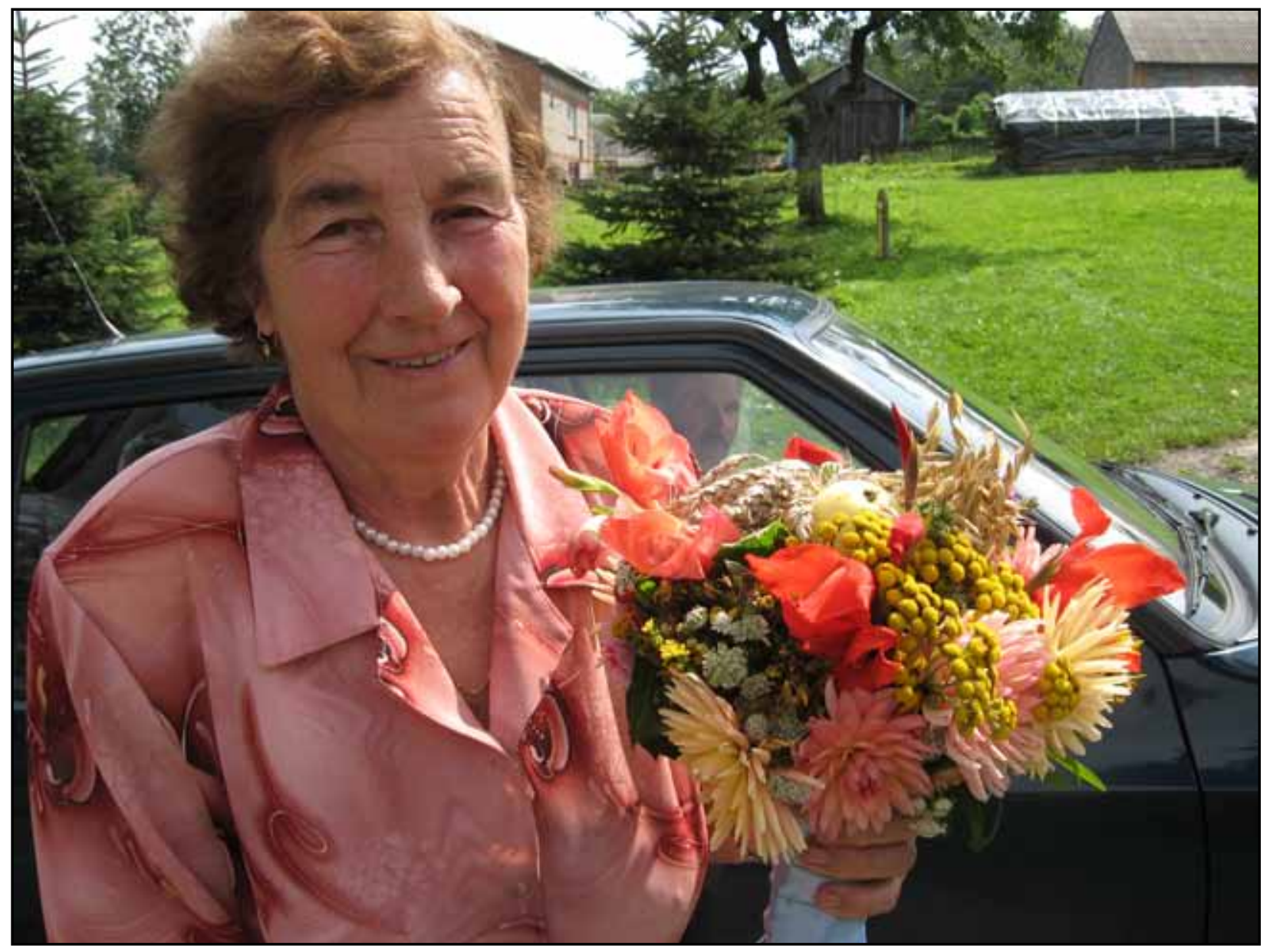

Figure 5. An Assumption Day bouquet from Stary Żmigród, Poland. 


\section{Łuczaj - Herbal Bouquets Blessed on Assumption Day in South-Eastern Poland: Freelisting versus photographic inventory}

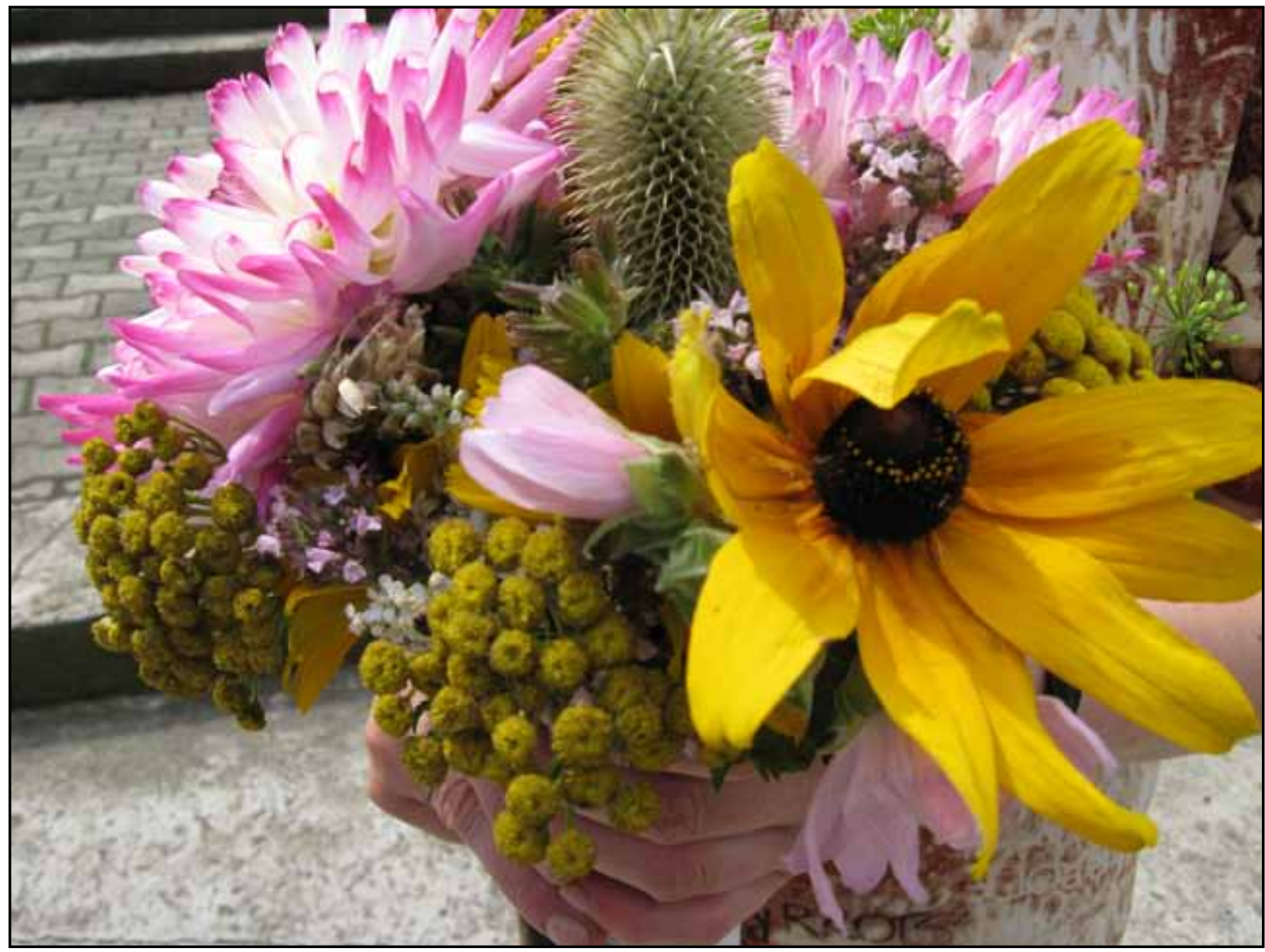

Figure 6. An Assumption Day bouquet from Stary Żmigród, Poland.

Most informants state that one can bless whatever plants one wants to, but very toxic plants (e.g., Aconitum spp.) should not be blessed. A few people told me that arable weeds should not be blessed unless they have medicinal value. In Cieszyna, the only weeds blessed used to be prickly thistles (probably Cirsium arvense (L.) Scop.), which after being blessed were planted back in the field upside down, "so that they would not grow again"

The bouquets have typically been used as medicine for animals, mainly cows (43\% of questionnaires). Respondents often mentioned that an infusion brewed from the whole bouquet helped cows to expel the placenta after birth. It was given to them for a few days. They claimed that cows which have recently given birth like bitter tastes and it helps them to recover. In some villages the infusion was made using the whole bunch steeped in a bucket of hot water, in some the bunch was crumbled first. It was not uncommon to bless as many bunches as one had cows.

Another frequently mentioned use $(21 \%)$ is protection from evil influences. That is why the bouquets are hung on walls, inside one's house or on farming premises. The bunches are still sometimes used for smudging in protective magic.

Only $11 \%$ of the respondents mentioned using the bouquets to heal people. Mainly St. John's wort and mint were taken out from bouquets and used in infusions. The blessed apples were eaten straight away to protect the owners of the bouquet from sore throats. Fourteen respondents (nearly 10\%) mentioned that the bouquets were left for a few days (weather permitting) in the garden, particularly among cabbages, to protect them from caterpillars. Thirteen respondents $(9 \%)$ remembered or still practiced, when sowing cereals, scattering the grains which had been blessed in the bouquet first. In Stary Żmigród guelder rose is blessed to bring a good wheat harvest and bladdernut fruits (Staphylea pinnata L.) are blessed to bring a good broad bean harvest. Seven respondents reported the protective power of the bouquets against storms and thunder, and six wrote that the bouquets may be laid under a deceased person's head. One person mentioned protection from ants in the house using blessed tansy, and another remembered planting a blessed thistle plant (C. arvense) upside-down to eradi- 
cate this weedy species. The bouquets are never thrown out. The remnants are usually burned (some people keep the bouquets for a few years in the attic, some only until the second of February, the Gromniczna day).

The blessing of the bouquets and their making is almost entirely a feminine activity now. Whenever I asked a man about them, he answered: "go to my wife, she knows about these things". Only one informant said that in his village it was the men who used to bring the bouquets. This change may have been brought about by the disappearance of horse carts. In the past a man often carried one or a few large bouquets (nearly his own size) in a horse-drawn cart. Making bouquets was a group activity, usually performed the day before the holiday. Children helped older people gather the right herbs. The properties of each particular species were discussed. St. John's wort was included in the largest amounts as this was a highly revered herb, not only was it used for a variety of mainly gastrointestinal ailments, for cows and humans, but it also protected newly-born babies from being abducted by evil fairies. They were believed to swap their ugly, crying in- fants for human babies, but they were scared of the St. John's wort strewn around the bed.

The bundle had to be very tight and even: an apple, some vegetables and a poppy head in the middle, then cereal, herbs and St. John's wort around it. The uneven ends of stalks were chopped with an axe, so the base was so even that it could stand upright without support. The bouquet was tied with a string or a red ribbon. Village people often talk about how messy and uneven the bouquets are in the town. One respondent told me that the bouquet must be so tight and thick that it can be left standing upright without a vase. I must admit myself that in the village of Nowica (close to the study area), whose bouquets I have studied before (Łuczaj 2009a), the few migrants from the city could be instantly recognized not by the composition of the bouquets but by a characteristic lack of "obsessive" tightness of the bouquets.

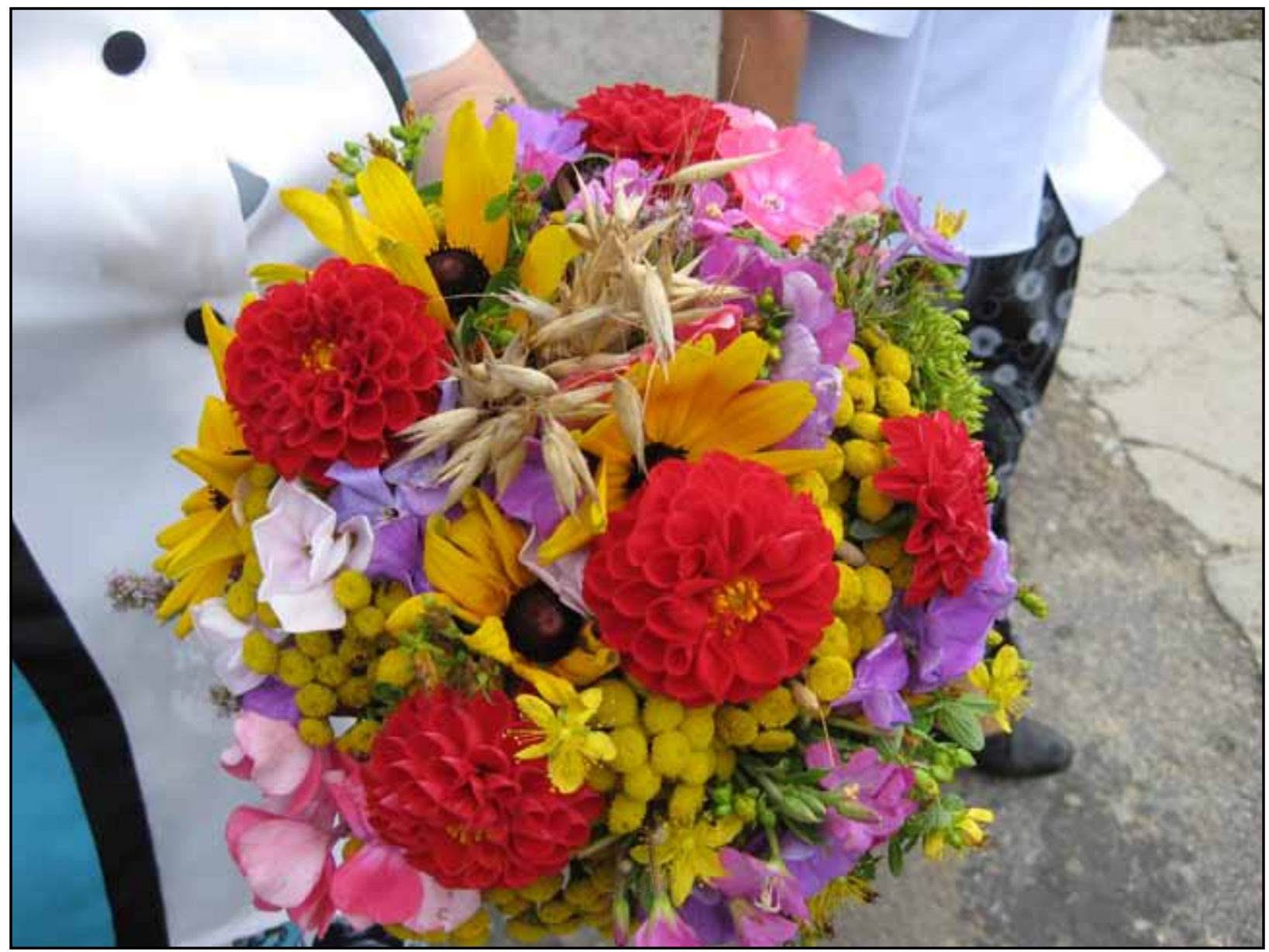

Figure 7. An Assumption Day bouquet from Stary Żmigród, Poland. 


\section{Łuczaj - Herbal Bouquets Blessed on Assumption Day in South-Eastern Poland: Freelisting versus photographic inventory}

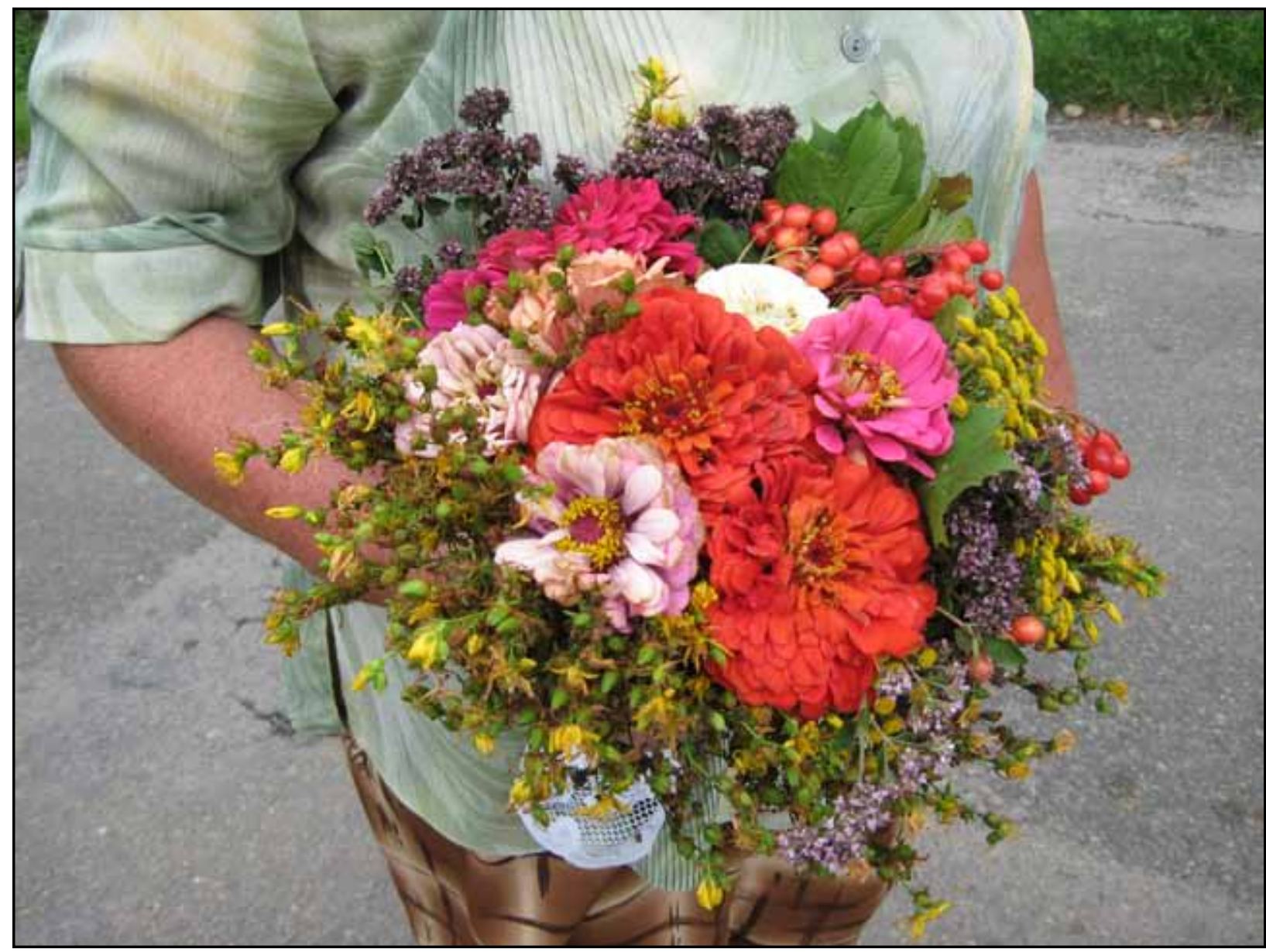

Figure 8. An Assumption Day bouquet from Stary Żmigród, Poland.

\section{Discussion}

\section{Changes in the composition of the bouquets}

The composition of the bouquets must have undergone drastic changes since the $19^{\text {th }}$ century. Out of forty-one taxa identified to at least generic level in historical data only twenty-eight were recorded in at least in one bouquet. What is more only a few of these taxa are still commonly blessed.

One of the most important reasons for the change in the composition of bouquets are vegetation transformations. Many of the blessed plants were aromatic or prickly herbs growing in pastures. Nowadays most pastures have been afforested or turned into hay meadows. This brought about a reduction in the blessing of such herbs as Centaurium spp., Cirsium spp. and Carlina vulgaris L.

Also, crops have been disappearing from the bouquets. The cultivation of opium poppy, once an important economic plant (the seeds are used in baking), was criminal- ized in the 1990s and now only a few poppies were found in the bunches. The same thing happened with the less frequently blessed cannabis (Cannabis sativa L.). Flax ( Linum usitatissimum L.) disappeared from the bouquets due to the cessation of cultivation.

For the question of which plants are no longer blessed the respondents listed 44 species altogether (most of them only once, but the species are still blessed in other villages). The most frequently mentioned species were opium poppy (18 answers) and marigold (6 answers).

Compared to the 19th century data (Kolberg 1974, Tync 1994) some plants which used to be grown in gardens are not blessed any more. These are mainly medicinal plants, such as Artemisia absinthium L. C. officinalis, Inula helenium L., and Salvia officinalis L. The tradition of cultivating and blessing $I$. helenium (called wielkie ziele, i.e. the great herb) has survived in only two villages - Cieszyna near Strzyżów and Trzcinica near Jasło. Some medicinal herbs are not blessed any more because they were eradicated by the use of chemicals. These are annual weeds from arable fields e.g. cornflower (Centaurea cyanus L.) 
and chamomile (C. recutita). Also, the decreasing importance of medicinal herbs is responsible for their smaller presence in the bouquets to be replaced by purely ornamental plants.

An interesting phenomenon is the use of a plant called przestrach (Polish for fright). According to its name it was used to cure children from fright. Fright was a commonly recognized illness in folk disease classification. Children were administered the plant when they were surprised by something scary. The illness manifested itself by restlessness, crying or even a temperature and more serious symptoms. In order to cure fright various means were applied. One of them was 'the fright plant', applied as incense or infusion. These practices are still remembered by many respondents and applied, though rarely, nowadays (particularly around Żmigród). Similar practices are known from other parts of Poland as well (Niebrzegowska 2000). Fright is not one species of plant. In Brzezowa and Osiek Jasielski it is greater burnet (Sanguisorba officinalis L.) and in Stary Żmigród it is lesser burnet (Sanguisorba minor Scop.). Kolberg (1974) also reported przestrach from Wzdów, but he described it as a plant with 'pods like vetch', so it cannot be Sanguisorba. The two people who can identify fright in the Beskid Niski mountains (south of study area), which is inhabited by Carpatho-Rusyns (a Ukrainian minority), and call it perestrah (Ukrainian equivalent of przestrach) and identify it as Impatiens nolitangere L. (In Świątkowa, exploding pods were believed to cure fright) and Chamaenerion angustifolium (L.) Holub (an infusion was applied in Komańcza).

In the Strzyżów area (Strzyżów, Cieszyna, Kozłówek) ziele wiatrowe, i.e., "herb of wind" was the most important blessed herb. This was identified by two respondents as Ononis arvensis L.. The same species has a similar name in some Ukrainian dialects further east - vitrovoj-zillja (Kobìv 2004), whereas vitrove žilia is known among Slovakian Carpatho-Rusyns from the Svidnik area (Varchol 2002). They use this name for various medicinal plants (e.g., loosestrife, Lythrum salicaria L. and wild pea Lathyrus sylvestris L.), used as incense to treat people who

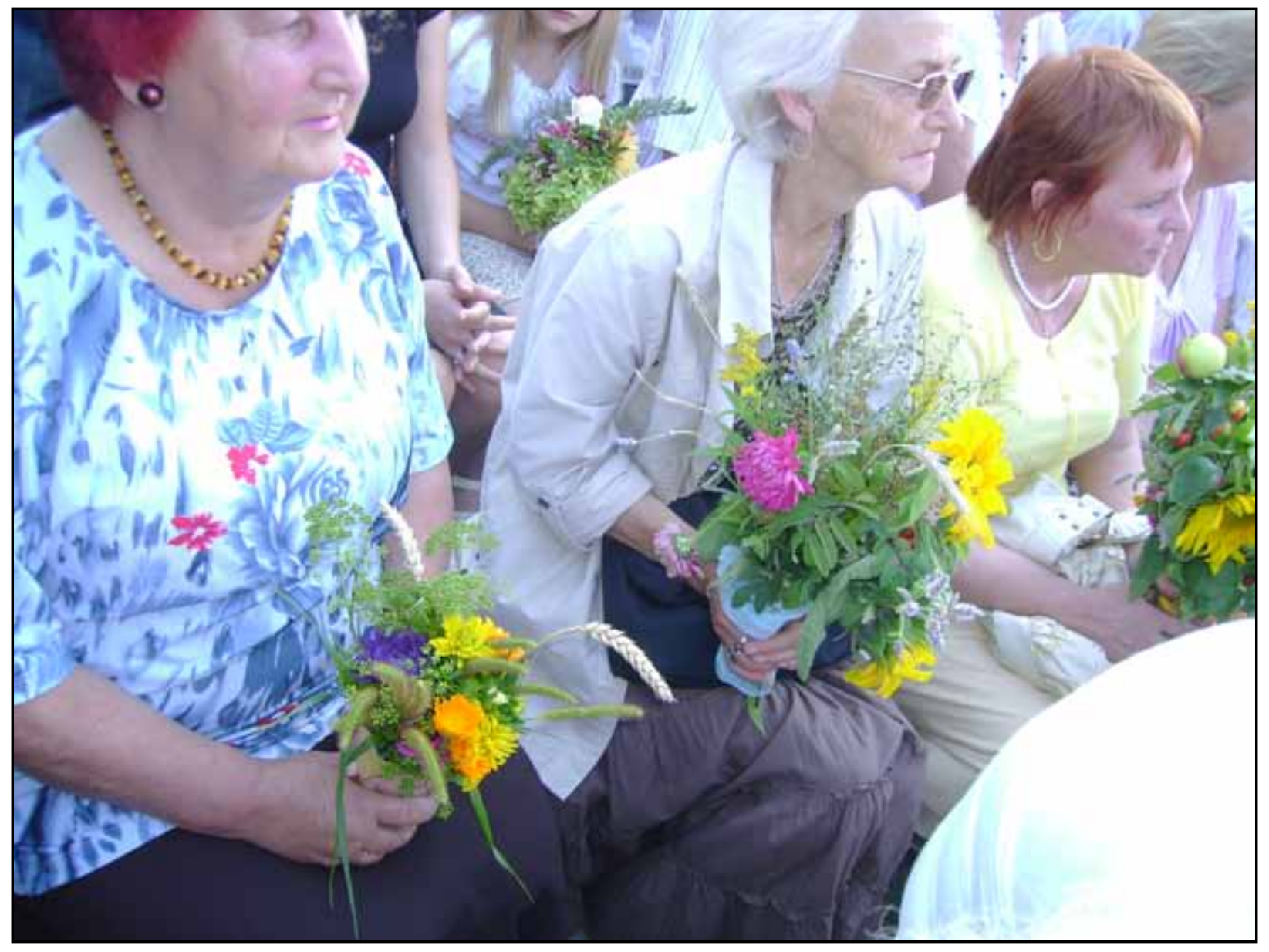

Figure 9. Assumption Day bouquet blessing in Krosno. In south-eastern Poland most families bring bouquets to church. They are usually blessed by women. Photo by Michał Łuczaj. 


\section{Łuczaj - Herbal Bouquets Blessed on Assumption Day in South-Eastern Poland: Freelisting versus photographic inventory}

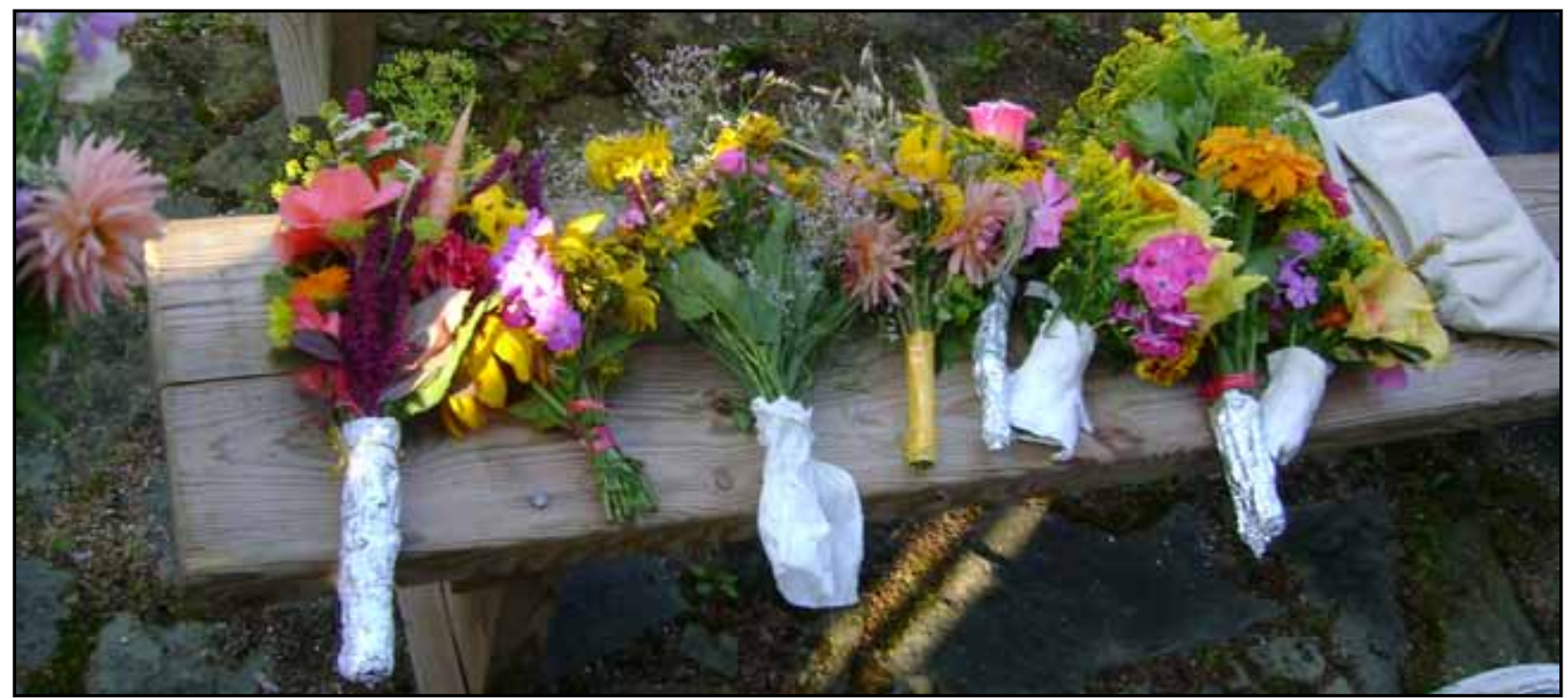

Figure 10. Assumption Day Bouquets from Krosno, Poland. Town bouquets like these usually have less species in general, and less medicinal and wild plants in particular. Photo by Michał Łuczaj.

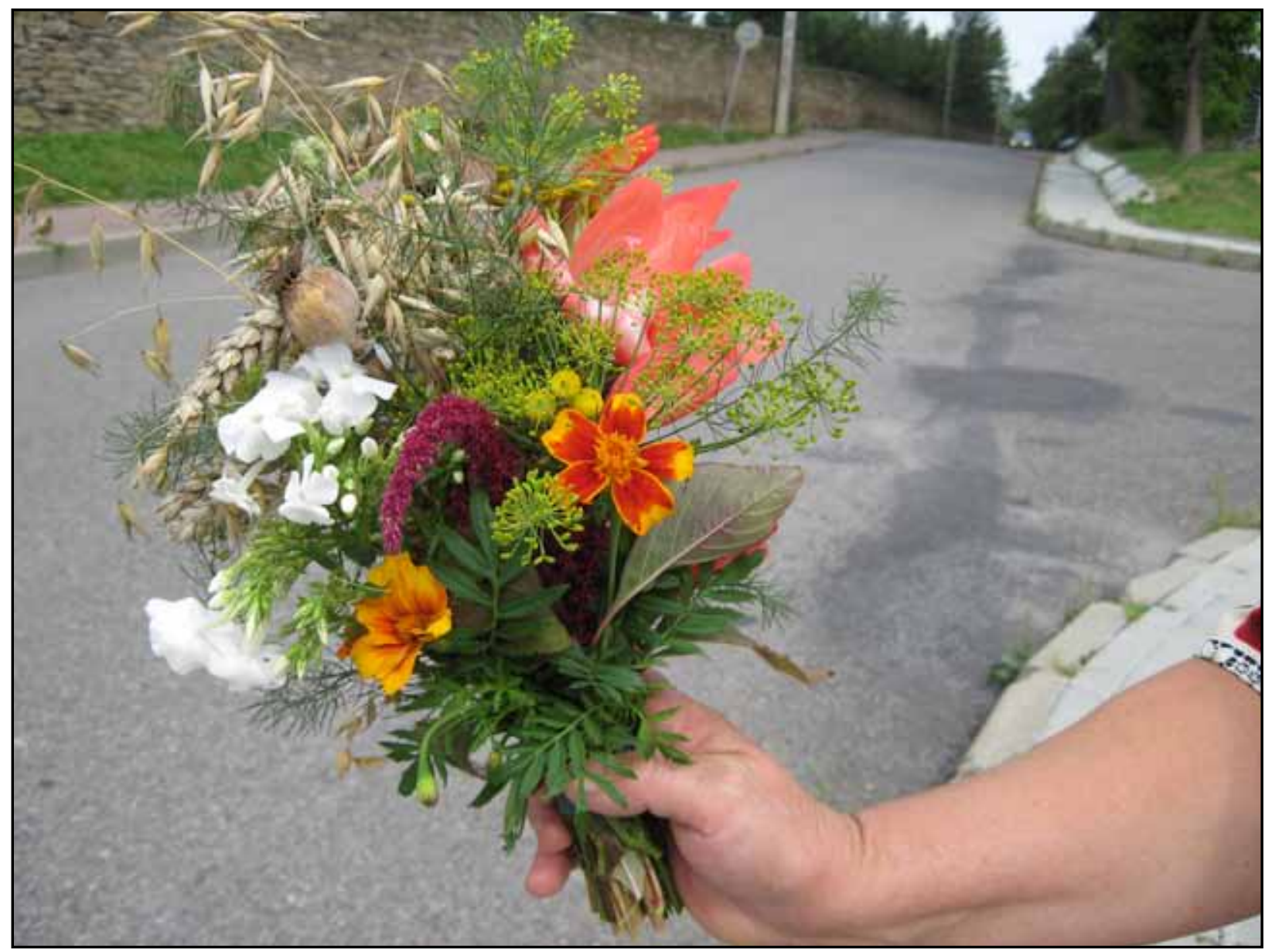

Figure 11. An Assumption Day bouquet from Dukla, Poland. 


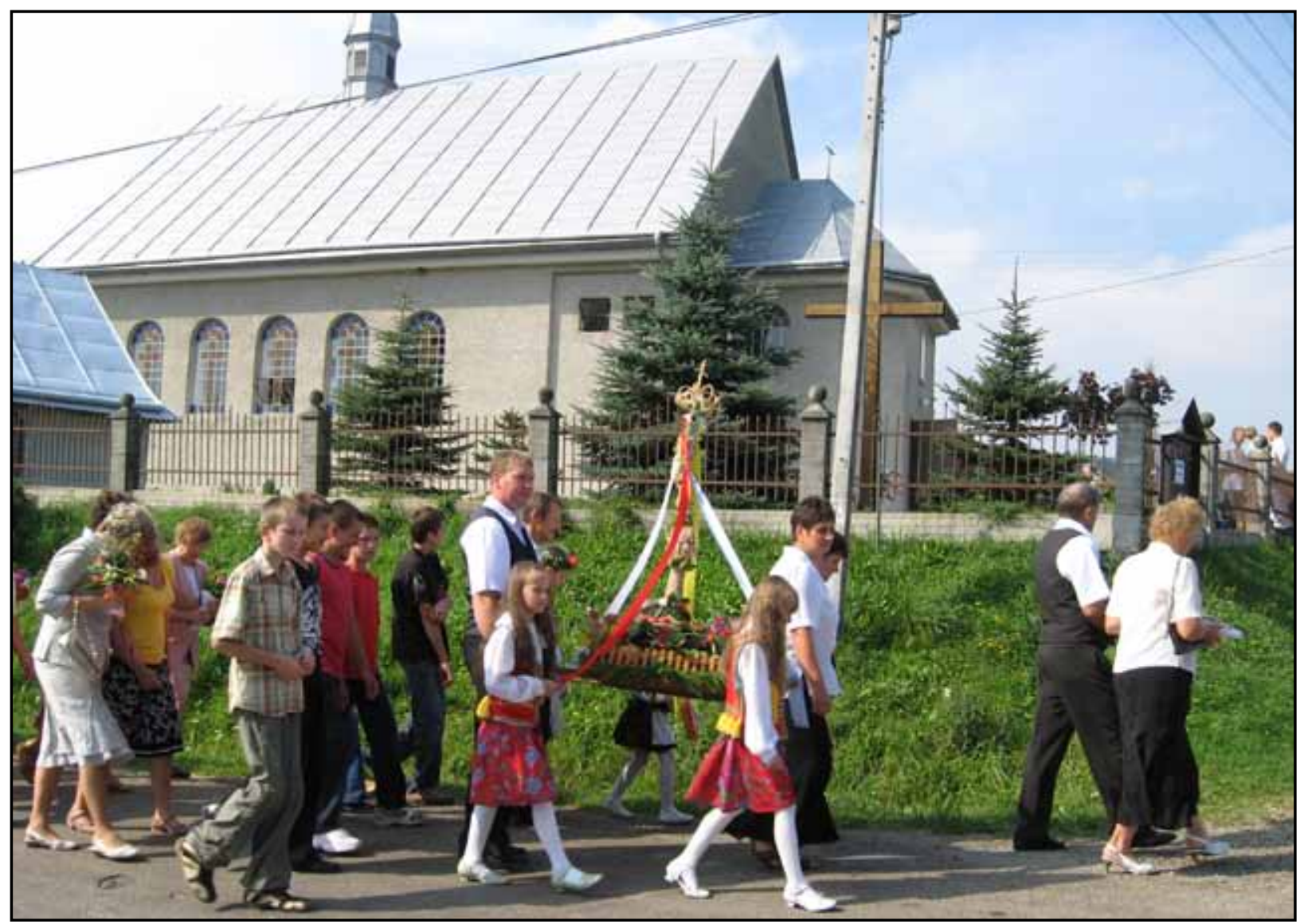

Figure 12. The Assumption Day bouquet blessing is often accompanied by harvest celebrations in SE Poland.

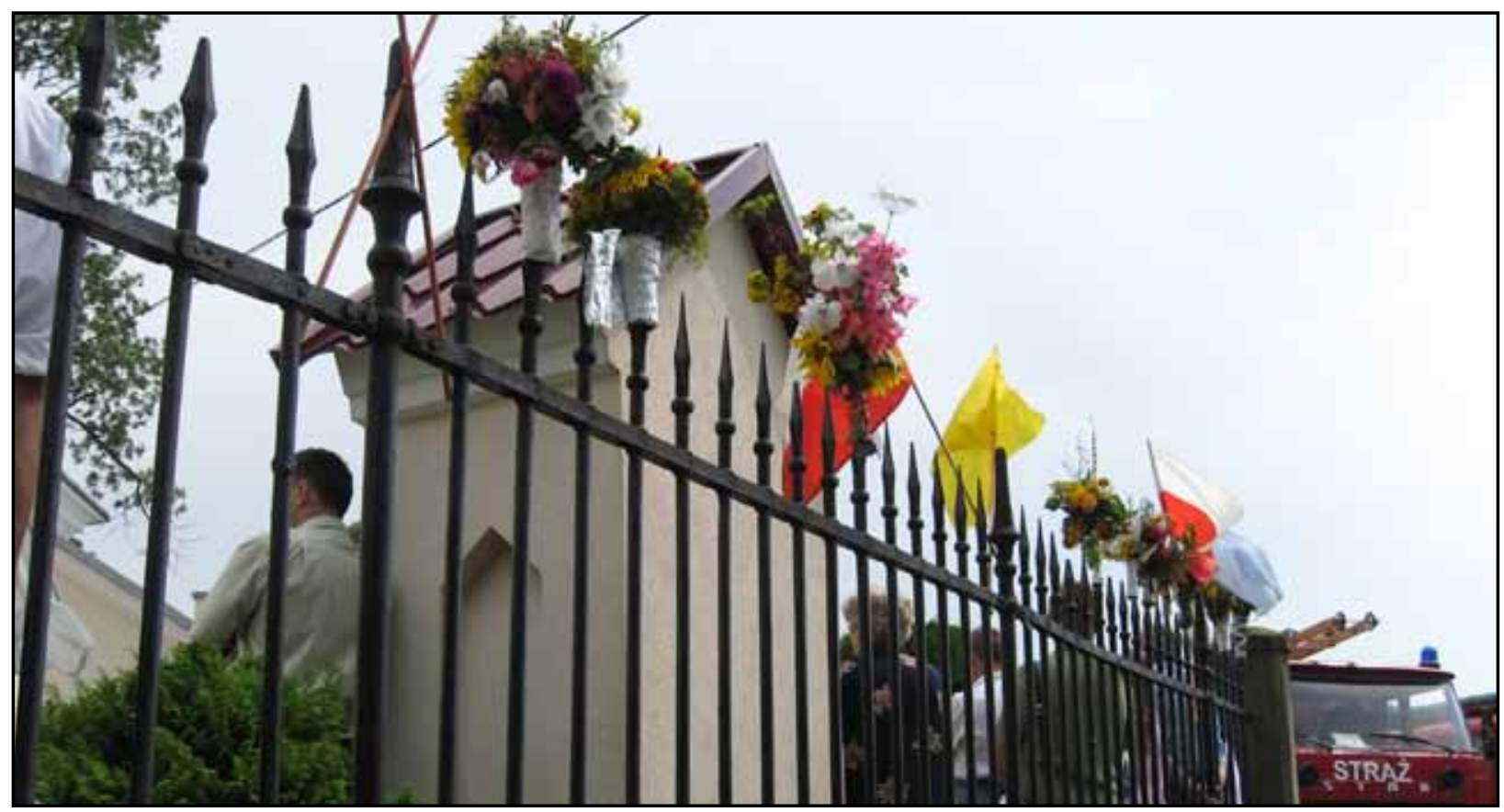

Figure 13. In Nienaszów, Poland an innovation in the mode of the Assumption Day blessing ceremony has occurred. The bouquets are stuck on fence poles instead of being held during the mass. 


\section{Łuczaj - Herbal Bouquets Blessed on Assumption Day in South-Eastern Poland: Freelisting versus photographic inventory}

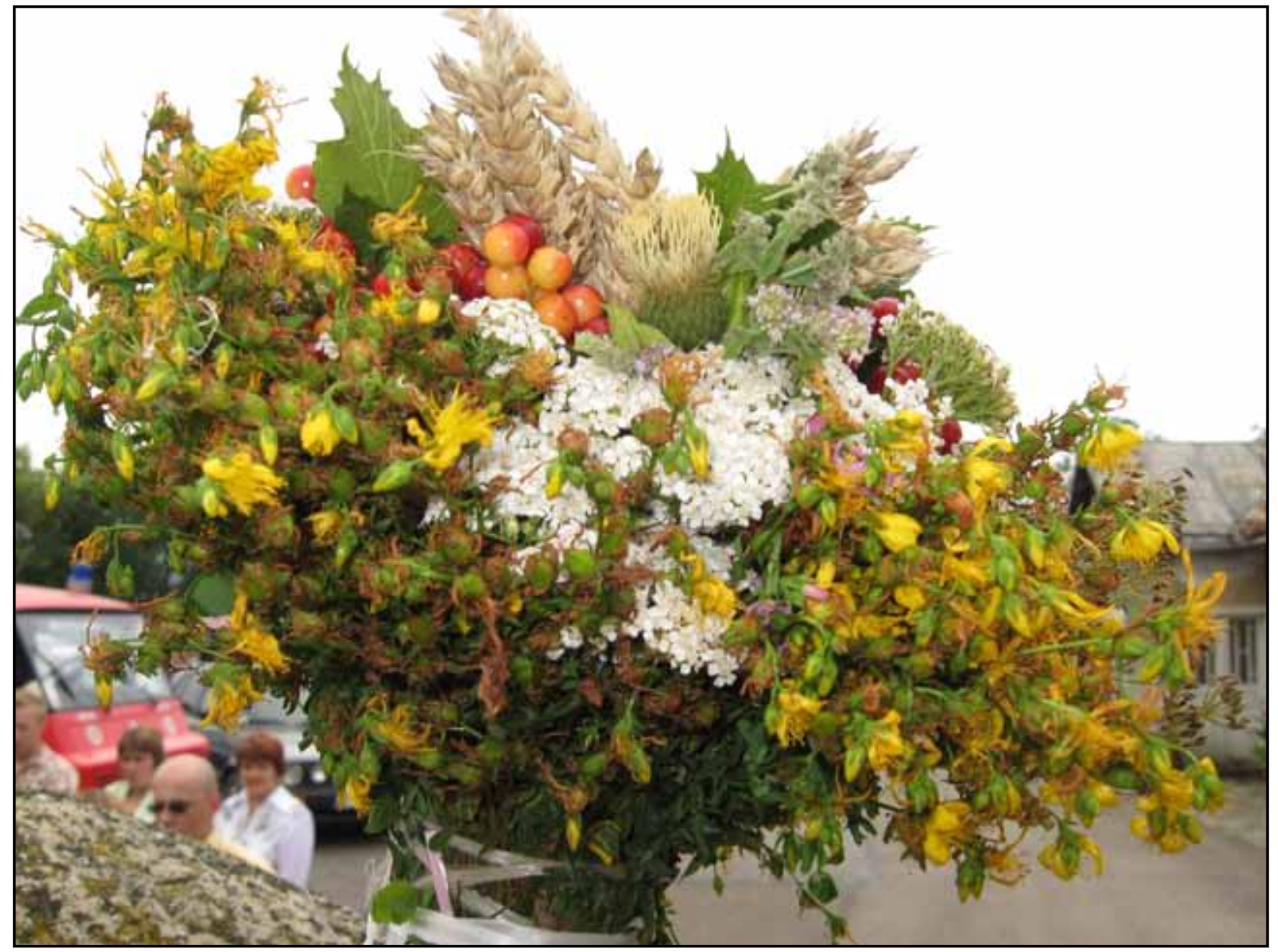

Figure 14. An Assumption Day bouquet from Nienaszów, Poland.

were ill from draughts. In one village even a 'ninefold wind herb' is applied for this purpose (nine species). An inhabitant of Polany, adjacent to this area (on the Polish side, also a Carpatho-Rusyn village) also remembers a pinkflowering vitryče zila, blessed on Assumption Day and used as incense for ill people.

Knapweed (Centaurea jacea L.) used to be another important herb. It was called here twarde ziele ('hard herb'), mocne ziele ('strong herb') or twardostój ('stand upright'). It was applied for bathing anemic children.

There is no uniform opinion among respondents as to which of the herbs is most important. Hypericum is the most frequently quoted plant as an answer to this question (25 responses). A few respondents also mentioned cereals (9), Artemisia vulgaris L. (8), C. recutita (6), Thymus pulegioides L. (5), V. opulus (4), H. annuus (3), I. helenium (3), T. vulgare (3) and Eupatorium cannabinum L. (3).

In Zarszyn, hemp agrimony (E. cannabinum), called szadziec there, is regarded as the king of all herbs, and wild oregano (Origanum vulgare L.), called lebiódka there, is the queen. In no other villages is this belief now preserved, although both plants are commonly blessed. However in Stary Żmigród and Krościenko Wyżne, Eupatorium (in the former called siedziec, in the latter pościółka) is regarded as the most important herb. The belief that these two plants are the king and the queen also occurred over $150 \mathrm{~km}$ westward, in Kraków area (Udziela 1931), thus it is likely that this is a historical reminisce of a once more common belief. Apart from $\mathrm{O}$. vulgare there is only one other species believed to be the queen of herbs - Artemisia vulgaris L. (in some villages around Jasło).

Another historical cultural practice is the tradition of blessing the twigs and fruits of bladdernut (S. pinnata ) (e.g., in Łysa Góra, Nienaszów, Stary Żmigród, Mytarz). Its importance in the local folklore was discussed in another article (Łuczaj 2009b). Bladdernut seeds were once commonly used to make rosaries and its hard wood to make various utensils, e.g., dashers for butter-making. In Stary Żmigród people believe that blessing bladdernut fruits brings a good broad bean harvest. 
In the $19^{\text {th }}$ century some intoxicating hallucinogenic Solanaceae plants (plant names szaleń and wyriot - typical for this group of plants) were blessed in the area (Tync 1994), however no such plants were blessed in 2009. Also another plant, commonly believed to be endowed with magical properties - Bryonia alba L. (przestęp - this name is universally used in the whole country), reported both by Tync and Kolberg and remembered by one of my respondents, disappeared from the bouquets.

\section{The usefulness of combining an emic and an etic approach}

The results of the study show that digital photographs can be a quick and valuable tool in documenting ethnobotanical traditions in countries with temperate climates were the flora is relatively well known and not-sodiverse. Good quality photographic inventories are sufficient to identify most taxa to the species level and nearly all taxa to the genus level.

The value of combining an emic and etic approach in ethnobotany has already been emphasized by Zent (1996).
In this study photographs provide us with a frequency list of the plants blessed nowadays. On the other hand use of questionnaires made it possible to distinguish between important plants (crops and medicinal herbs) - identified to the species or genus level, and accidental additions to the bouquets, usually bulked as 'garden flowers' or 'flowers'.

The combination of the two above-mentioned techniques also makes it possible to grasp the temporal changes in a tradition. The people's image of a tradition is often set in the past, as respondents often refer to plants (e.g., opium poppy), which are no longer blessed, in the present tense, so the combination of freelisting and photographic documentation does not only reveal the insider-outsider difference, but also a contrast between the past and the present.

\section{Plant names with religious connotations}

Most local names recorded in the study are simple names, usually referring to a monotypical genus or a few similar, not distinguished species from the same genus. Two

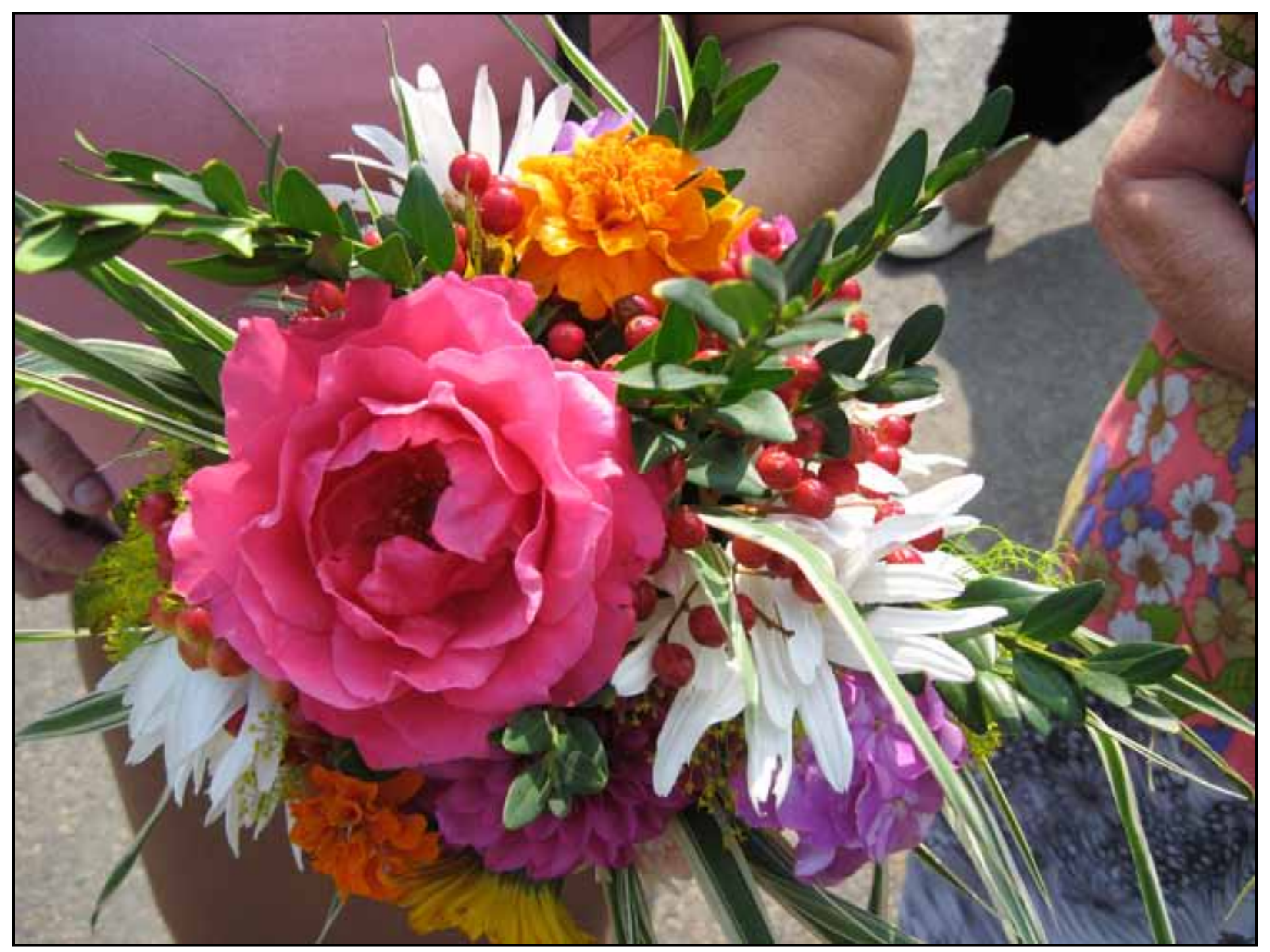

Figure 15. An example of an Assumption Day bouquet composed mainly of garden plants, Łysa Góra, Poland. 


\section{Łuczaj - Herbal Bouquets Blessed on Assumption Day in South-Eastern Poland: Freelisting versus photographic inventory}

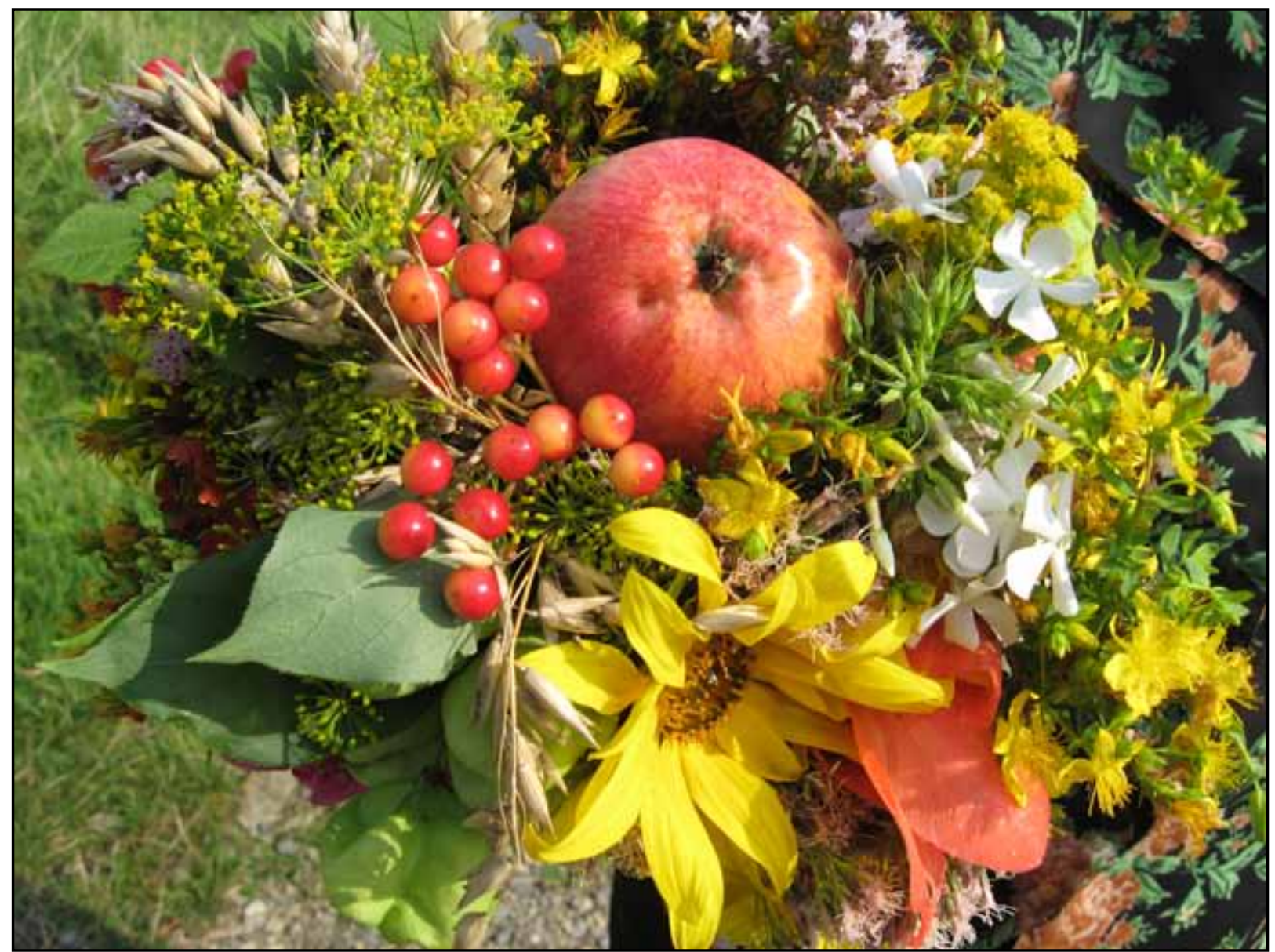

Figure 16. An example of a traditional Assumption Day bouquet from Łysa Góra, Poland.

of very few binominal names are (e.g., mak ogrodowy, 'garden poppy' - P. somniferum, and mak czerwony, 'red poppy' - Papaver rhoeas L.). Many of the blessed plants actually constitute covert taxa for the local population most respondents recognize the plants which should be used but cannot name them. Out of the most common plants, respondents had the biggest problems with naming $O$. vulgare and $L$. salicaria.

A special category of taxa are those with names created by combining holy names and everyday objects. Udziela (Köhler 1996a, 1996b, Udziela 1931) was already fascinated by them and recorded them in his study from Kraków area. Such names exist in the study area and are still remembered by older people (Table 3 ). The names which are remembered include: paluszki Matki Boskiej ('Virgin Mary's fingers') or Boże paluszki ('God's fingers) and their variants, applied to C. angustifolium and Epilobium spp. The local names of Agrimonia eupatorium L. were created in a similar fashion to the word for 'apple' or 'pear', the name for Omalotheca sylvatica (L.) Sch. Bip. \& F.W. Schultz - by adding holy names to 'rye' (Table $3)$. These names are often identical to those recorded by
Udziela near Kraków, over a hundred years ago. Hence, similarly to the belief in the royal nature of Eupatorium and Origanum, these names were probably a part of a widespread and relatively homogenous Assumption Day folklore. Some of the presumed reasons for this homogenization were church festivals (on the occasion of indulgences) organized on Assumption day in numerous sanctuaries containing holy paintings of the Virgin Mary. Pilgrims coming from different areas with bouquets to bless must have compared the plants and their names. The homogeneity of names may also be a sign of a high cultural status of these plants. Interestingly most of these plants, once widely known under holy names (Epilobium, Omalotheca, C. vulgaris, etc.), are apart from $A$. eupatorium, not used in contemporary Polish ethnomedicine to the point that no one remembers their medicinal uses and they are not discussed in Paluch's (1984) monograph of Polish ethnomedicine. 
Table 3. Local names with religious connotations recorded for plants used in Assumption Day bouquests in Podkarpackie administrative region, Poland.

\begin{tabular}{|l|l|l|}
\hline Scientific name & Local name & English translation \\
\hline \multirow{2}{*}{$\begin{array}{l}\text { Epilobium spp. s.I. (including Chamaenerion } \\
\text { angustifolium (L.) Holub) }\end{array}$} & Boże paluszki & God's fingers \\
\cline { 2 - 3 } & $\begin{array}{l}\text { paluszki Matki Boskiej, Bożej } \\
\text { / Matki Bożej paluszki }\end{array}$ & Mary's fingers \\
\hline \multirow{3}{*}{ Agrimonia eupatorium L. } & jabłuszka Matki Boskiej & Mary's apples \\
\cline { 2 - 3 } & Boże jabłuszka & God's apples \\
\cline { 2 - 3 } & gruszki Matki Bożej & Mary's pears \\
\cline { 2 - 3 } & rajskie jabłuszka & Eden's apples \\
\hline Carlina vulgaris L. & osetek Matki Bożej & Mary's thistle \\
\hline Linaria vulgaris Mill. & buciki Matki Bożej & Mary's shoes \\
\hline Artemisia abrotanum L. & Boże drzewko & God's tree \\
\hline Omalotheca sylvatica (L.) Sch.Bip. \& F.W. Schultzz & Matki Boskiej żyto & Mary's rye \\
\cline { 2 - 3 } & Boże żyto & God's rye \\
\hline
\end{tabular}

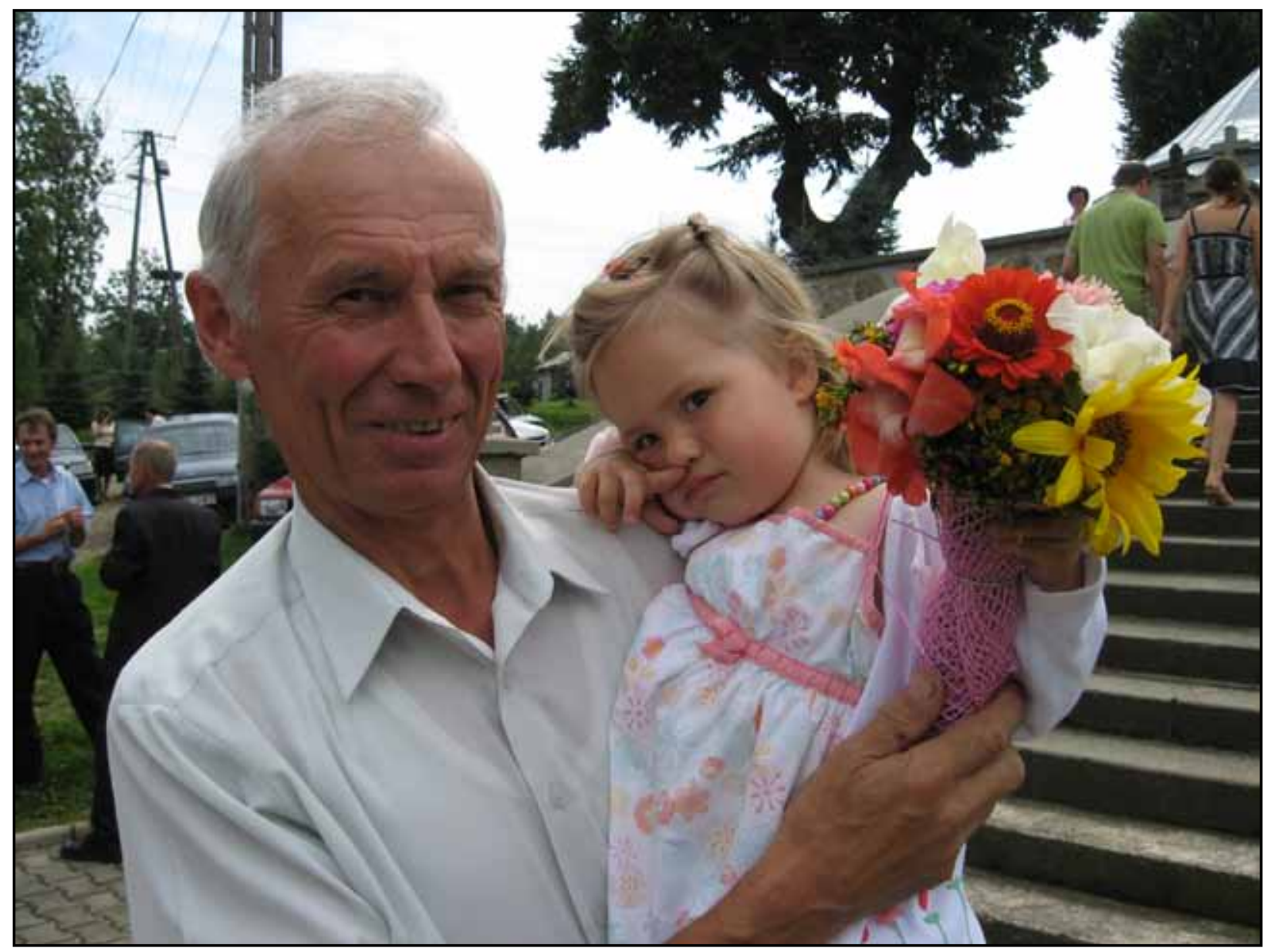

Figure 17. Children are sometimes encouraged to make their own Assumption Day bouquets or to hold the bouquets of their parents' or grandparents'. 


\section{Łuczaj - Herbal Bouquets Blessed on Assumption Day in South-Eastern Poland: Freelisting versus photographic inventory}

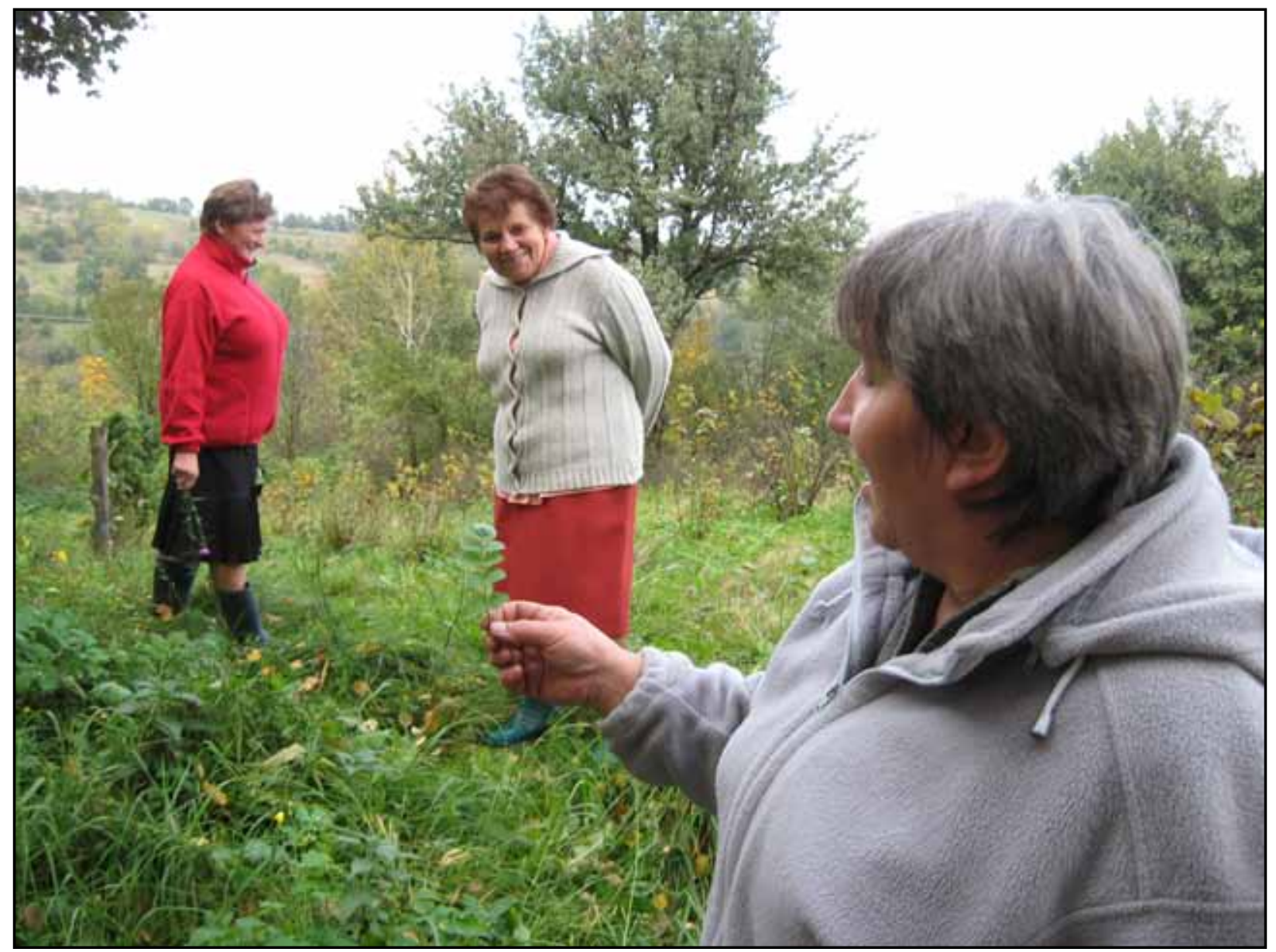

Figure 18. Determining local plant names in the field in SE Poland. The three most knowledgeable informers from Cieszyna who could provide 70 local names of plants in one walk.

\section{Conclusions}

The questionnaires and the list made using photographs gave similar results. The significant differences concerned mainly two types of plants. Ornamentals, new to the bouquets or unimportant for their composition, were underrepresented in the bouquets. On the other hand some species mentioned in the questionnaires are not blessed any more, mainly due to habitat changes.

Surprisingly the average length of the freelist given by respondents is longer than the mean number of species per bouquet, contrary to a general trend when using this method of collecting data (Quinlan 2005). This may be caused by the fact that the interviewees were mainly knowledgeable people and that the tradition is undergoing devolution - more species are remembered than actually blessed. During interviews and questionnaires respondents often struggled to remember old names. They usually remembered the location of the plant better than its name or appearance. One respondent tried to explain to me which purple-flowering plant was 'Mary's finger." I made a bouquet containing thirty purple flowered species from around her house, but she could not find it there. Then she remembered that it grew in a ditch fifty years ago, she walked a few hundred meters and came back with the plant she meant.

A few respondents explained the detailed route that they make on the morning or evening before the Assumption day service. Some plants are collected at the top of the hill, some by the river, and some in the garden. In order to obtain rarer but important plants, such as $C$. vulgaris or $S$. pinnata, people would walk a few kilometers. Nowadays when people spend less time in the countryside, the disappearance of a species from the location they used to gather it for decades means its disappearance from the particular bouquets, as people are too busy to look for new locations and they do not care so much about the presence of a particular species in the bouquet. Very often some sort of divergence occurs. Some people remember the plants which should be blessed, but do not know their names, many names mentioned by the $19^{\text {th }}$ century au- 
thors are not recognized by local inhabitants. On the other hand some remember names without recognizing the plants, a clear sign of the devolution of the local traditional plant knowledge. Determination of the factors responsible for these two different trajectories of the degeneration of traditional knowledge could be an interesting issue for further study.

The composition of the bouquets has changed a lot since the $19^{\text {th }}$ century, while in the past it contained mainly crops and medicinal plants, now a large proportion of plants are ornamental garden plants without connection to local ethnomedicine or farming.

\section{Acknowledgments}

I would like to thank all the friends and students who helped me in distributing the questionnaires, particularly Jan Szeliga, Barbara Drozd, Bartek Kielski-Bardanaszwili and Wanda Rak. I am greatly indebted to Prof. Krzysztof Oklejewicz (Rzeszów University) and Wojciech
Szymański (Jagiellonian University) for their help in identifying some taxa, and Dr. Krzysztof Ruszel (Ethnographic Museum in Rzeszów), Dr. Ülle Sillasoo (Tallin Uniersity) and dr. hab. Piotr Köhler (Jagiellonian Uniersity) for help in literature search.

\section{Literature Cited}

Aumüller, S. 1974. Kräuterweihe im Burgenland, Der "Weihbuschn". Burgenländische Heimatblätter 36(1):2544.

Berlin, B. 1992. Ethnobiological Classification: Principles of categorization of plants and animals in traditional societies. Princeton University Press, Princeton, New Jersey.

Christanell, A., B. Vogl-Lukasser, C. R. Vogl \& M. Gütler. 2010. The Cultural Significance of Wild-gathered Plant Species in Kartitsch (Eastern Tyrol, Austria) and the Influence of Socioeconomic Changes on Local Gathering Practices. Pages 51-75 in Ethnobotany in the New Eu-

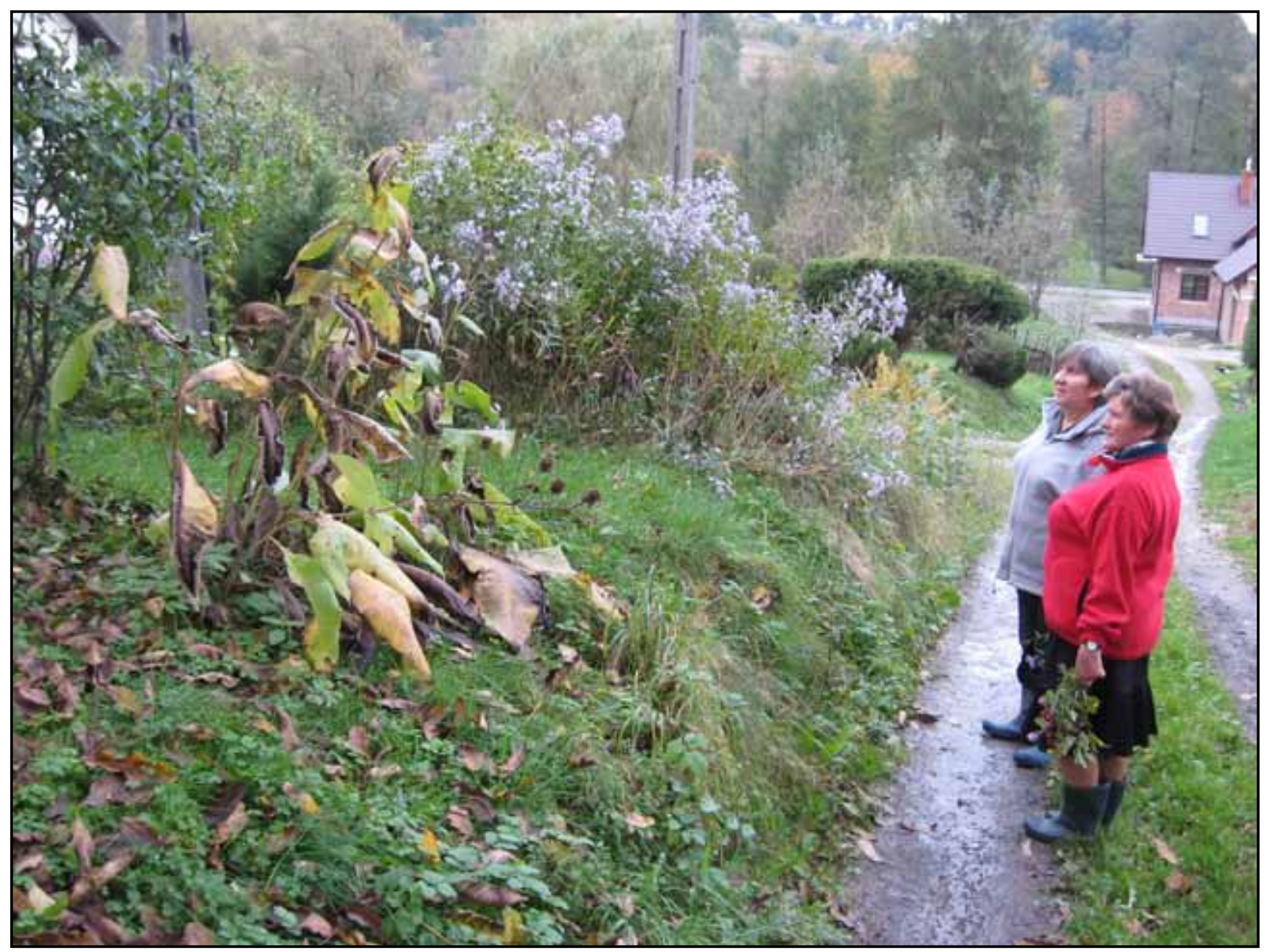

Figure 19. This Inula helenium L. specimen (on the left) is grown specially to be blessed on Assumption Day in SE Poland. 


\section{Łuczaj - Herbal Bouquets Blessed on Assumption Day in South-Eastern Poland: Freelisting versus photographic inventory}

rope: People, health and wild plant resources. Edited by P. de Santayana, M.A. Pieroni \& R. Puri. Berghahn Press, Oxford.

Cotton, C.M. 1996. Ethnobotany: Principles and applications. Wiley, Chichester.

Czyż, L.M. 1993. Bukiety zielne święcone w dniu Matki Boskiej Zielnej. Pp. 141-146 in Historia leków naturalnych, t.3. Edited by B. Kuźnicka. Instytut Historii Nauki PAN, Warszawa.

Headland, T., K. Pike \& M. Harris. 1990. Editors of Emics and Etics: The insider/outsider debate. Sage Publications, Thousand Oaks, California.

Höfler, M. 1912. Der Fraueudreissiger. Zeitschrift für österreichische Volkskunde 18:133-I6I.

Klepacki, P. 2007. Etnobotanika w Polsce - przeszłość i teraźniejszość. Analecta - Studia i Materiały z Dziejów Nauki 16(1-2):191-245.

Kobìv, Y. 2004. Slovnik ukraïnskih naukovih nazv sudinnih roslin. Naukova Dumka, Kiïv.

Köhler, P. 1993. Ankieta Józefa Rostafińskiego z 1883 roku dotycząca ludowego nazewnictwa roślin w Polsce. Analecta 2(2):89-119.

Köhler, P. 1996a. Rośliny poświęcone kultowi Maryi w zielniku Seweryna Udzieli. Pp. 138-149 in Orędowniczko nasza. Kult Matki Bożej w polskiej kulturze ludowej. Edited by A. Spiss. Muzeum Etnograficzne w Krakowie, Kraków.

Köhler, P. 1996b. Zielnik Seweryna Udzieli - dokumentacja pracy „Rośliny w wierzeniach ludu krakowskiego”. Lud 80:179-186.

Kolberg, O. 1974. Sanockie - Krośnieńskie. Część I. Dzieła Wszystkie, t. 49. PTL, Wrocław-Poznań.

Libera, Z. \& A. Paluch. 1993. Lasowiacki zielnik. Varia Kolbuszowskie 2. Biblioteka Publiczna Miasta i Kminy w Kolbuszowej, Kolbuszowa.

Łozińska, J. 1883. Archival letter to Józef Rostafiński. Stored in the museum of the Botanic Garden of JagielIonian University.

Łuczaj, Ł. 2009a. Bukiety święcone w dniu Matki Boskiej Zielnej w Beskidzie Niskim i Dołach Jasielsko-Sanockich. Płaj 36:56-65.

Łuczaj, Ł. 2009b. Bladdernut (Staphylea pinnata L.) in Polish folklore. Rocznik Polskiego Towarzystwa Dendrologicznego 57:23-28.
Łuczaj, Ł. 2011. Changes in Assumption Day Herbal Bouquets in Poland: A nineteenth century study revisited. Economic Botany 65: in press.

Martin, G.J. 1995. Ethnobotany: A methods manual. Chapman and Hall, London.

Niebrzegowska, S. 2000. Przestrach od przestrachu: rośliny w ludowych przekazach ustnych. Wydawnictwo UMCS, Lublin.

Paluch, A. 1984. Świat roślin w tradycyjnych praktykach leczniczych wsi polskiej. Wydawnictwo Uniwersytetu Wrocławskiego, Wrocław.

Quinlan, M. 2005. Considerations for Collecting Freelists in the Field: Examples from ethobotany. Field Methods $17(3): 219-234$

Ruszel, K. 2004. Leksykon kultury ludowej w Rzeszowskiem. Muzeum Etnograficzne w Rzeszowie, Rzeszów.

Rostafiński, J. 1922. Wpływ przeżyć chłopięcych Mickiewicza na obrazy ostatnich dwu ksiąg Pana Tadeusza oraz o święceniu ziół na Matkę Boską Zielną. Polska Akademja Umiejętności, Wydział Filologiczny - Rozprawy 61(3,16):1-36.

Schroedel, J. \& J. Schroedel, 2006. The Everything Mary Book: The life and legacy of the blessed mother. Adams Media Corporation, Cincinnati, Ohio.

Sillasoo, Ü. 2009. Plants in Late Medieval festivals and customs in written and pictorial sources from southern central Europe. Environmental Archeology 14(1):76-89.

Szot-Radziszewska, E. 2005. Sekrety Ziół. Trio, Warszawa.

Thomas, E., I. Vandebroek \& P. Van Damme 2007. What Works in the Field? A comparison of different interviewing methods in ethnobotany with special reference to the use of photographs. Economic Botany 61(4):376-384.

Tync, B. 1994. Zwyczaje doroczne. Pp. 176-177 in Ziemia biecka. Lud polski w powiatach bieckim i grybowskim. Edited by S. Udziela. Sądecka Oficyna Wydawnicza WOK, Nowy Sącz.

Udziela, S. 1931. Rośliny w wierzeniach ludu krakowskiego. Lud 30:36-75.

Varchol, N. 2002. Roslini v narodnih povir'jah RusinivUkraïnciv Prjašivščini. EXCO, Edmonton, Canada Prešov, Slovakia. 
Wong, J.L.G. 2000. The Biometrics of Non-Timber Forest Product Resource Assessment: A review of current methodology. A report for ZF0077 pre-project of the Forest Research Programme of the United Kingdom Department for International Development. www.etfrn.org/etfrn/ workshop/ntfp/text.pdf
Zent, S. 1996. Behavorial orientations towards ethnobotanical quantification. Pp. 199-239 in Selected Guidelines for Ethnobotanical Research: A field manual. Edited by M.N. Alexiades \& J.W. Sheldon. New York Botanical Garden Press, Bronx, New York.

Appendix 1. Original text of the questionnaire used to conduct interviews about Assumption Day bouquets in the study area (Podkarpackie administrative region, Poland).

\begin{tabular}{|l|}
\hline 1. Jakie rośliny święci się w Waszej miejscowości w dzień Matki Boskiej Zielnej? \\
\hline 2. Czy są rośliny, które święcono dawniej, a teraz się nie święci? Jakie, od jak dawna i dlaczego? \\
\hline 3. Do czego używano tych bukietów po poświęceniu? \\
\hline $\begin{array}{l}\text { 4. Czy o jakichś roślinach święconych na Zielną mówiono, że to ojciec lub matka ziół, król lub królowa czy też } \\
\text { najważniejsze ze wszystkich ziół? }\end{array}$ \\
\hline
\end{tabular}




\section{Łuczaj - Herbal Bouquets Blessed on Assumption Day in South-Eastern Poland: Freelisting versus photographic inventory}

Appendix 2. Taxa occurring in Assumption Day bouquets reported in literature, but not listed in Table 1. XIX - presence in the $19^{\text {th }}$ century sources: T - Tync (1994), K - Kolberg (1974), L - Łozińska (1883).

\begin{tabular}{|c|c|c|c|c|}
\hline Local name(s) & Latin name or other identification & $\begin{array}{l}\text { \# of } \\
\text { photos }\end{array}$ & $\begin{array}{l}\text { \# of } \\
\text { questionnaires }\end{array}$ & $\mathrm{XIX}$ \\
\hline biedrzeniec & Pimpinella sp. & 0 & 0 & $\mathrm{~T}$ \\
\hline bukwica & Stachys officinalis (L.) Trevis. & 0 & 0 & $\mathrm{~K}$ \\
\hline czosnek & Allium sativum $\mathrm{L}$. & 2 & 7 & $\mathrm{~K}$ \\
\hline dziewanda, dziewanna & Verbascum sp. & 0 & 4 & $\mathrm{~T}$ \\
\hline groch & Pisum sativum $\mathrm{L}$. & 0 & 0 & $\mathrm{~T}, \mathrm{~K}$ \\
\hline jałowiec & Juniperus communis L. & 0 & 0 & L \\
\hline konopia & Cannabis sativa L. & 0 & 1 & $\mathrm{~T}$ \\
\hline kopelnik, kopytnik & Asarum europaeum L. & 0 & 5 & $\mathrm{~T}$ \\
\hline lubcyk, lubczyk & Levisticum officinale W.D.J.Koch & 1 & 5 & $\mathrm{~T}, \mathrm{~K}$ \\
\hline maruna & Tanacetum parthenium (L.) Schultz-Bip & 2 & 3 & $\mathrm{~K}$ \\
\hline $\begin{array}{l}\text { osetek Panny Marii, } \\
\text { osetek Matki Bożej }\end{array}$ & Carlina vulgaris $\mathrm{L}$. & 2 & 5 & $\mathrm{~T}$ \\
\hline pasternak & Pastinaca sativa $\mathrm{L}$. & 0 & 0 & $\mathrm{~T}$ \\
\hline przestęp & Bryonia alba L. & 0 & 1 & $\mathrm{~T}, \mathrm{~K}$ \\
\hline przewrotnik, przewrotek & Alchemilla spp. & 0 & 0 & $\mathrm{~T}, \mathrm{~L}$ \\
\hline rozchodnik & Sedum acre L. (?) & 0 & 0 & $\mathrm{~L}$ \\
\hline ślipie, rumian wielki & Leucanthemum vulgare Lam. s.I. & 9 & 0 & $\mathrm{~T}$ \\
\hline szparagi & Asparagus officinalis L. & 6 & 0 & $\mathrm{~K}$ \\
\hline tureckie proso & Amaranthus sp. & 4 & 4 & $\mathrm{~K}$ \\
\hline wielgie ziele, wielkie ziele & Inula helenium L. & 0 & 4 & $\mathrm{~T}, \mathrm{~K}$ \\
\hline \multicolumn{5}{|l|}{ Unidentified taxa: } \\
\hline baśnica & Rumex sp. or Aegopodium podagraria L? & - & - & $\mathrm{T}$ \\
\hline bluszcz & $\begin{array}{l}\text { name usually used for Hedera helix L. but } \\
\text { description does not correspond to it }\end{array}$ & - & - & $\mathrm{K}$ \\
\hline józefek & Hyssopus officinalis L. or Polygala sp.? & - & - & $\mathrm{T}$ \\
\hline koszyczki & - & - & - & $\mathrm{T}$ \\
\hline kotki & - & - & - & $\mathrm{K}$ \\
\hline krzyżowa trawa & - & - & - & $\mathrm{K}$ \\
\hline lulek, szaleń, wyriot & probably a hallucingenic Solanaceae species & - & - & $\mathrm{T}$ \\
\hline osetek Pana Jezusa & some spiny Asteraceae species & - & - & $\mathrm{T}$ \\
\hline piorunki & - & - & - & $\mathrm{T}$ \\
\hline przestrach & - & - & - & $\mathrm{T}, \mathrm{K}$ \\
\hline rumian dziki, przymiotnik & some Asteraceae species & - & - & $\mathrm{T}$ \\
\hline ślaz & some Malvaceae species? & - & - & $\mathrm{T}$ \\
\hline $\begin{array}{l}\text { szczoteczki, oset } \\
\text { gręplarski }\end{array}$ & - & - & - & $\mathrm{T}$ \\
\hline szczotki & - & - & - & $\mathrm{K}$ \\
\hline warkoczyki Panny Marii & - & - & - & $\mathrm{T}$ \\
\hline wawrzyńcowe ziele & - & - & - & $\mathrm{K}$ \\
\hline zgrzebycki & - & - & - & $\mathrm{T}$ \\
\hline ziele świętego Wawrzyńca & - & - & - & $\mathrm{K}$ \\
\hline
\end{tabular}


